PATRICIA LIMA PRAES

Estudo radiográfico retrospectivo das alterações do proventrículo em psitacídeos

SÃO PAULO

2013 


\section{Estudo radiográfico retrospectivo das alterações do proventrículo em psitacídeos}

Dissertação apresentada ao Programa de PósGraduação em Clínica Cirúrgica Veterinária da Faculdade de Medicina Veterinária e Zootecnia da Universidade de São Paulo, para obtenção do título de Mestre em Ciências.

\section{Departamento:}

\section{Cirurgia}

Área de concentração:

Clínica Cirúrgica Veterinária

\section{Orientador:}

Prof. Dr. Angelo João Stopiglia

De acordo:

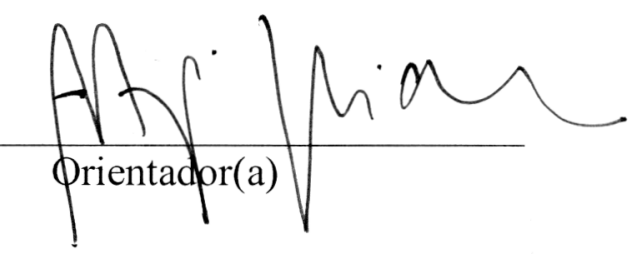

São Paulo

2013 
Autorizo a reprodução parcial ou total desta obra, para fins acadêmicos, desde que citada a fonte.

DADOS INTERNACIONAIS DE CATALOGAÇÃO-NA-PUBLICAÇÃO

(Biblioteca Virginie Buff D'Apice da Faculdade de Medicina Veterinaria e Zootecnia da Universidade de Säo Paulo)

Praes, Patricia Lima

Estudo radiográfico retrospectivo das alteraçỏes do proventriculo em psitacideos. I

Patricia Lima Praes, - 2013

$74 \mathrm{f}:$ :

Dissertaçāo (Mestrado) - Universidade de Sāo Paulo. Facuidade de Medicina Veterinária e Zootecnia. Departamento de Cirurgia, Sāo Paulo, 2013.

Programa de Pós-Graduaçăo: Clínica Cinúrgica Veterinária.

Área de concentraçăo: Clínica Cirúrgica Veterinária.

Orientador: Prof. Dr. Angelo Joăo Stopiglia.

1. Estudo radiográfico. 2. Proventriculo, 3. PDD. 4. Aves, 5. Psitacideos. 1. Título. 
FACULDADE DE MEDICINA VETERIXÁRIA E ZOOTECNIA

Comissão de Ética no Uso de Animais

\section{CERTIFICADO}

Certificamos que o Projeto intitulado "Estudo radiográfico restrospectivo das alterações do proventrículo em psitacídeos", protocolado sob o n ${ }^{\circ} 2311 / 2011$, utilizando arquivo radiográfico de 20 (vinte) aves entre papagaios, araras e calopsitas, sob a responsabilidade do(a) Prof. Dr. Angelo João Stopiglia, está de acordo com os princípios éticos de experimentação animal da "Comissão de Ética no uso de animais" da Faculdade de Medicina Veterinária e Zootecnia da Universidade de São Paulo e foi aprovado em reunião de 15/8/2012.

We certify that the Research "Radiographic retrospective study of changes in the proventriculus in psittacines", protocol number 2311/2011, utilizing radiographic file of 20 (twenty) birds including parrots, macaws and cockatiels, under the responsibility Prof. Dr. Angelo João Stopiglia, agree with Ethical Principles in Animal Research adopted by "Ethic Committee in the use of animals" of the School of Veterinary Medicine and Animal Science of University of São Paulo and was approved in the meeting of day 8/15/2012.

São Paulo, 10 de junho de 2013.

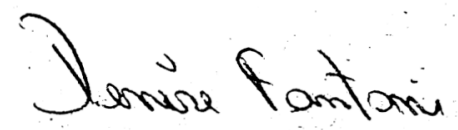

Denise Tabacchi Fantoni

Presidente 


\section{FOLHA DE AVALIAÇÃO}

Autor: PRAES, Patrícia Lima

Título: Estudo radiográfico retrospectivo das alterações do proventrículo em psitacídeos

Dissertação apresentada ao Programa de Pós-Graduação em Clínica Cirúrgica Veterinária da Faculdade de Medicina Veterinária e Zootecnia da Universidade de São Paulo, para obtenção do título de Mestre em Ciências

Data:

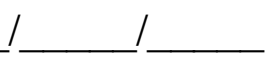

Banca Examinadora

Prof. Dr.

Instituição: Julgamento:

Prof. Dr.

Instituição: Julgamento:

Prof. Dr. Instituição: Julgamento: 
Dedico este trabalho aos meus pais, Maria e Erlon, irmãos, Pablo e Patrick, e ao meu marido, amigo e companheiro, Paulo Henrique.

O apoio que sempre me proporcionaram, foram fundamentais para a concretização do meu sonho.

A Giuli. 


\section{AGRADECIMENTOS}

Primeiramente, agradeço a Deus, por me proporcionar intensa realização, como a conclusão deste trabalho.

Ao Prof. Dr. Angelo Stopiglia pelo incentivo desde o início, por estar sempre disposto a me ajudar e por muito contribuir para a minha formação profissional.

Ao Prof. Dr. Franklin de Almeida Sterman (in memorian), como médico veterinário, professor, ex-orientador. Minha eterna gratidão por confiar em mim.

Ao Prof. Dr. Benedicto Wlademir De Martin e Prof. Salvador Urtado, pela elaboração das cartas de referência.

A Silvana Maria Unruh, pelo auxílio na interpretação dos exames radiográficos e por muito ter me ensinado durante este convívio.

Ao Prof. Dr. Stefano Carlo Filippo Hagen, pela paciência e auxilio na rotina do depto de imagem do HOVET.

A Paulo Henrique Oliveira Praes, pelo "tratamento" das imagens digitais.

A Marta Brito Guimarães, pelo incentivo, indicações e idéias trocadas a respeito do tema abordado.

A equipe Estatística Certa, pelo desenvolvimento das análises estatísticas.

A Elza Maria Rosa Bernardo Faquim, pela revisão ágil e precisa das diretrizes para apresentação de dissertações e teses na FMVZ-USP.

A Belarmino Ney Pereira e Lívia dos Santos Gimenes, secretário do Programa de Pós-Graduação em Clínica Cirúrgica Veterinária da FMVZ-USP, pela orientação quanto à parte burocrática. 


\section{RESUMO}

PRAES, P. L. Estudo radiográfico retrospectivo das alterações do proventrículo em psitacídeos. [Retrospective radiographic study of proventricular abnormalities among psittacines]. 2013. 74 f. Dissertação (Mestrado em Ciências) - Faculdade de Medicina Veterinária e Zootecnia, Universidade de São Paulo, São Paulo, 2013.

Este estudo retrospectivo revisa os achados radiográficos em exames simples e contrastados de 38 aves psittaciformes com alterações no proventrículo. Os dados foram obtidos do Serviço de Diagnóstico por imagem do departamento de cirurgia junto ao Hospital Veterinário da Faculdade de Medicina Veterinária e Zootecnia da Universidade de São Paulo, durante o período de janeiro de 2004 a abril de 2012. A distribuição das alterações, assim como as suas respectivas espécies e idades, foram estudadas. O sexo das aves não foi considerado neste estudo. A espécie Amazona aestiva (papagaio-verdadeiro) alcançou a porcentagem mais elevada $(44,8 \%)$ entre as diversas ordens, seguidos pelos Nymphicus hollandicus (Calopsita) $(28,9 \%)$. Neste período de oito anos, os sintomas mais comuns observados na anamnese foram a "apatia/prostração" e "anorexia/prostração" (52,63\% cada). Entre as suspeitas clínicas mais frequentes, a doença da dilatação do proventrículo (PDD) foi a mais citada $(26,32 \%)$. O achado radiográfico mais frequentemente observado foi a "dilatação do proventrículo por conteúdo de radiodensidade gás e líquido" $(34,21 \%)$. A medição do proventrículo foi um dado descrito em $34,84 \%$ dos laudos. Dentre as aves estudadas com alterações radiográficas em proventrículo, o exame radiográfico contrastado por sulfato de bário foi solicitado em $26,32 \%$ dos casos, onde o achado radiográfico mais comum foi a "retenção do meio de contraste ou evolução lenta do mesmo". Dentre os casos com suspeita clínica de PDD, os únicos nos quais foi possível obter confirmação foram aqueles em que foi solicitado o exame contrastado. Algumas aves também exibiram alterações radiográficas inespecíficas. A dilatação de proventrículo em si não é patognomônica para PDD, visto que esta pode vir de forma atípica e que há diversas outras doenças que causam alterações semelhantes.

Palavras-chave: Estudo radiográfico. Proventrículo. PDD. Aves. Psitacídeos. 


\begin{abstract}
PRAES, P. L. Retrospective radiographic study of proventricular abnormalities among psittacines. [Estudo radiográfico retrospectivo das alterações do proventrículo em psitacídeos] 2013. 74 f. Dissertação (Mestrado em Ciências) Faculdade de Medicina Veterinária e Zootecnia, Universidade de São Paulo, São Paulo, 2013.
\end{abstract}

This retrospective study examines radiographic findings of plain and contrastenhanced examinations of 38 psittacine birds presenting proventricular abnormalities. The data were obtained by the Image Diagnostic Service of the Veterinary Hospital of the School of Veterinary Medicine and Animal Science of the University of São Paulo between January 2004 and April 2012. The distribution of the abnormalities, as well as the birds' species and ages, were also investigated. The birds' sex was not taken into account. The highest percentage among the different orders (44.8\%) was observed among specimens of Amazona aestiva (Blue-fronted Parrot), followed by Nymphicus hollandicus (Cockatiel) (28.9\%). In the eight-year period of the study, the most common symptoms were "apathy/weakness" and "anorexia/weakness" (52.63\% each.) Proventricular Dilatation Disease (PDD) was the most frequent clinical suspicion $(26.32 \%$.) The most commonly observed radiographic abnormality was a "Proventricular dilatation caused by content of gas and water radiodensity" $(34.21 \%$.) The measurements of the proventriculus were described in $34.84 \%$ of all reports. Among the birds studied with radiographic alterations in proventriculus, radiographic examination contrasted by barium sulfate was required in $26.32 \%$ of cases. The most common findings were "retention or slow transit of the contrast agent." The only cases with a clinical suspicion of PDD for which it was possible to obtain a confirmation were those for which a contrast-enhanced examination was ordered. Some birds also presented radiographic abnormalities of uncertain diagnosis. A proventricular dilatation in itself is not pathognomonic of PDD inasmuch as said disease may present in an atypical manner and several other diseases may cause similar abnormalities.

Keywords: Radiographic study. Proventriculus. PDD. Birds. Psittacines. 


\section{LISTA DE ILISTRAÇÕES}

Quadro 1 - Tempo ideal para individualização de órgãos após administração em $20 \mathrm{~mL} / \mathrm{kg}$ de suspensão sulfato de Bário $25 \%$ em seis exemplares de

Amazona aestiva

Figura 1 - Exame radiográfico simples em projeção laterolateral $(A)$ e ventrodorsal (B) de papagaio-verdadeiro adulto. Presença de acentuada dilatação de proventrículo por conteúdo gasoso e alimentar (heterogêneo) medindo $5.0 \mathrm{~cm}$ (eixo craniocaudal) $\times 3.0 \mathrm{~cm}$ (eixo ventrodorsal)

Figura 2 - Exame radiográfico contrastado em projeção laterolateral (A) e ventrodorsal (B) com administração de contraste de bário no caso clínico da figura 1. O animal apresentou evolução lenta da progressão do contraste do inglúvio para proventrículo, e ainda com dilatação de proventrículo e falha de preenchimento por conteúdo alimentar

Figura 3 - Exame radiográfico simples em projeção laterolateral de papagaioverdadeiro adulto. Presença de acentuada dilatação de proventrículo por conteúdo gasoso e heterogêneo

Figura 4 - Exame radiográfico simples em projeção laterolateral de papagaioverdadeiro adulto. Presença de dilatação de proventrículo por conteúdo radiodensidade gás e líquido medindo até $3,0 \mathrm{~cm}$ no eixo ventrodorsal e conteúdo de radiodensidade líquido em inglúvio

Anexo A, Figura 5 - Sistema digestório das aves

Anexo B, Figura 6 - Cavidades gástricas dos psitacídeos 


\section{LISTA DE TABELAS}

Tabela 1 -

Tabela 2 -

Tabela 4

Tabela 5 -

Tabela 6 -

Tabela 8

Tabela $9-$

Tabela $10-$

Tabela $11-$
Distribuição com as frequências absolutas $(\mathrm{N})$ e relativas (\%) de 38 aves, selecionadas com alteração em proventrículo ao laudo radiográfico, segundo a taxonomia - HOVET-FMVZ-USP - 20042012

Distribuição da frequência absoluta $(\mathrm{N})$ e relativa (\%) das manifestações clínicas de 38 aves selecionadas com alteração em proventrículo ao laudo radiográfico, de acordo com sintomas apresentados - HOVET-FMVZ-USP - 2004-2012

Frequência absoluta $(\mathrm{N})$ e relativa (\%) de 10 aves com exame radiográfico contrastado, dentre as 38 aves estudadas com alteração no proventrículo ao laudo radiográfico, de acordo com sintomas apresentados - HOVET-FMVZ-USP - 2004-2012

Frequência absoluta $(\mathrm{N})$ e relativa (\%)de 38 aves estudadas com alteração no proventrículo ao laudo radiográfico, de acordo com a suspeita clínica - HOVET-FMVZ-USP - 2004-2012 .

Frequência absoluta $(\mathrm{N})$ e relativa (\%) de 10 aves com exame radiográfico contrastado, dentre as 38 aves estudadas com alteração no proventrículo ao laudo radiográfico, de acordo com a suspeita clínica - HOVET-FMVZ-USP - 2004-2012

Frequência absoluta $(\mathrm{N})$ e relativa (\%) de 38 aves estudadas com alteração no proventrículo ao laudo radiográfico, de acordo com a evolução dos históricos em prontuários - HOVET-FMVZ-USP - 2004 2012

Frequência absoluta $(\mathrm{N})$ e relativa $(\%)$ dos exames complementares solicitados (além do exame radiográfico simples) de 38 aves estudadas com alteração no proventrículo ao laudo radiográfico de acordo com a modalidade solicitada - HOVET-FMVZ-USP - 20042012

Frequência absoluta $(\mathrm{N})$ e relativa $(\%)$ de 38 aves com alterações no proventrículo descritas ao laudo radiográfico, segundo os achados radiográficos - HOVET-FMVZ-USP - 2004-2012

Frequência absoluta (N) e relativa (\%) segundo as achados radiográficos aos exames contrastados de 10 aves, dentre as 38 aves estudadas com alteração no proventrículo ao laudo radiográfico HOVET-FMVZ-USP - 2004-2012.

Distribuição numérica $(\mathrm{N})$ de 38 aves com alterações no proventrículo descritas ao laudo radiográfico, analisando a frequência de suspeita clínica de acordo com as espécies - HOVET-FMVZ-USP - 2004-2012

Distribuição numérica $(\mathrm{N})$ de 38 aves com alterações no proventrículo descritas ao laudo radiográfico, analisando a frequência de suspeita clínica de acordo com idades dos animais - HOVET-FMVZ-USP 2004-2012

Distribuição de 10 aves com exame radiográfico contrastado (dentre as 38 aves estudadas com alteração no proventrículo ao laudo radiográfico) em relação às suspeitas de PDD (clínica e ao laudo 
radiográfico), de acordo com a espécie, idade e tipo de exame radiográfico - HOVET-FMVZ-USP - 2004-2012

Tabela 13- Distribuição numérica de 38 aves estudadas com alteração no proventrículo ao laudo radiográfico, analisando a frequência de suspeita clínica de acordo com os achados radiográficos - HOVETFMVZ-USP - 2004-2012.

Tabela $14-$

Distribuição numérica de 38 aves, analisando a frequência de sintomas de acordo com os achados radiográficos. HOVET-FMVZ-USP, 20042012 


\section{LISTA DE ABREVIATURAS E SIGLAS}

$\mu$ micrômetro

nm nanômetro

EUA Estados Unidos da América

FMVZ Faculdade de Medicina Veterinária e Zootecnia

HOVET Hospital Veterinário

kV quilovolts

PV Proventrículo

PDD Proventricular Dilatation Disease

TGI Trato gastrointestinal

VCI Departamento de cirurgia

USP Universidade de São Paulo 


\section{LISTA DE SÍMBOLOS}

$\mathbf{N}$ ou $\mathbf{n}$ distribuição numérica

p-valor resultados da significância estatística pelo teste de Igualdade de Duas Proporções

\% distribuição percentual

$\leq \quad$ menor ou igual a

$\geq \quad$ maior ou igual a 


\section{SUMÁRIO}

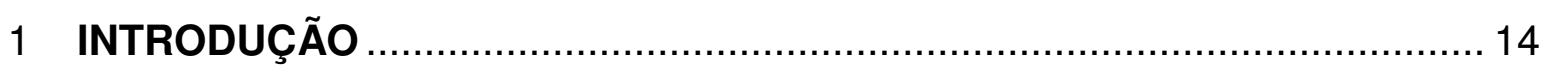

2 REVISÃO DE LITERATURA …......................................................... 16

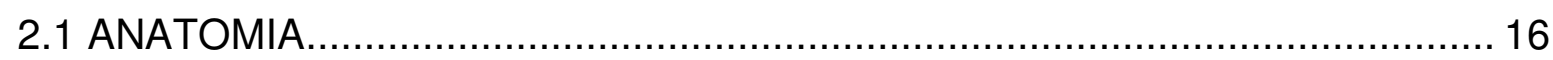

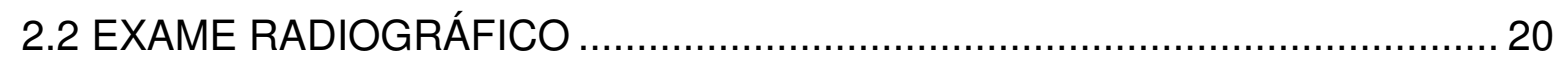

2.2.1 Métodos de posicionamento radiográfico e de contenção ................... 21

2.3 AFECÇÕES DO PROVENTRÍCULO ........................................................ 25

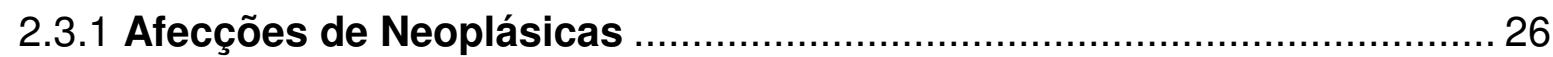

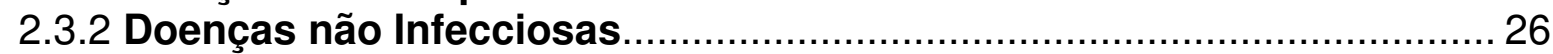

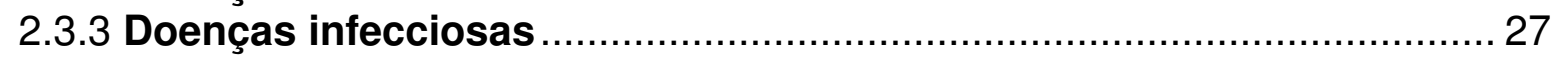

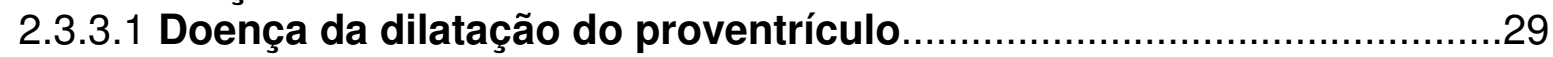

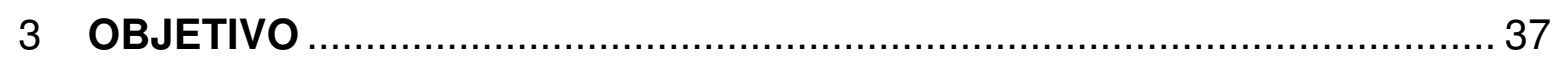

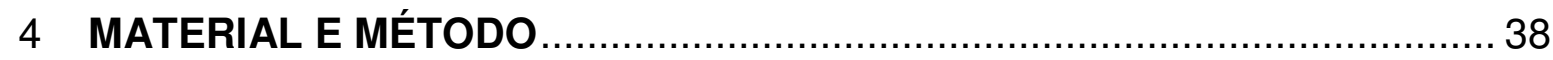

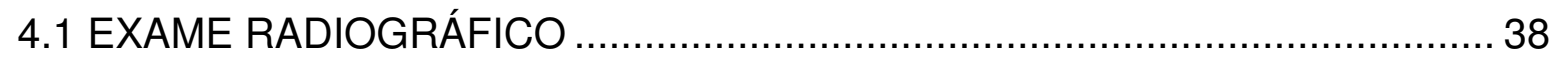

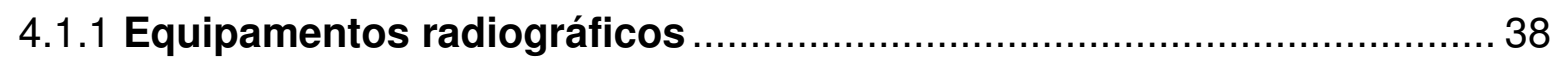

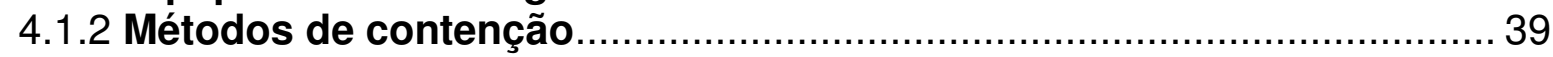

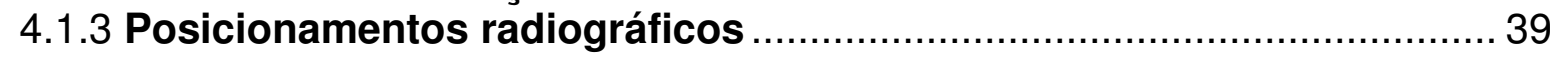

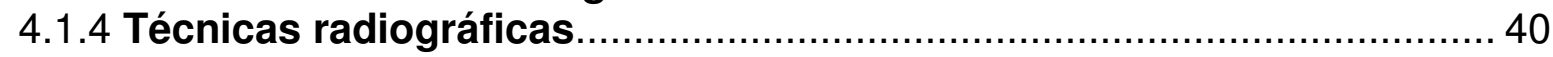

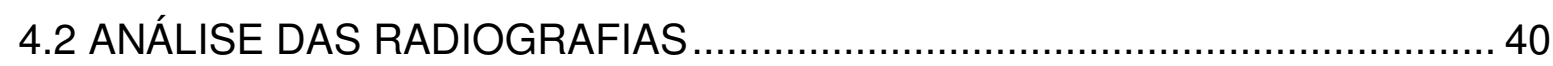

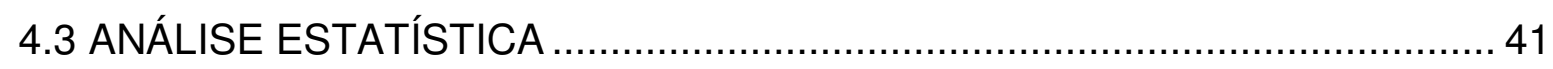

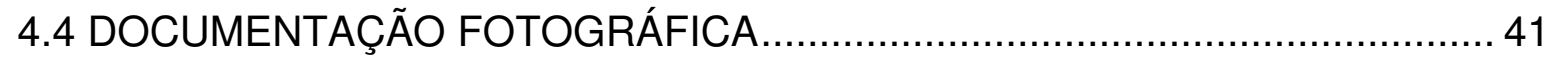

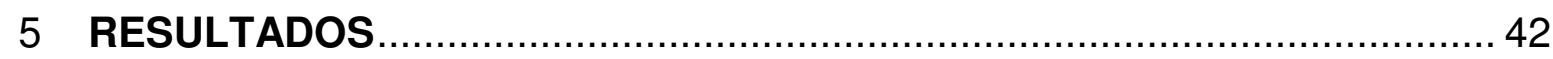

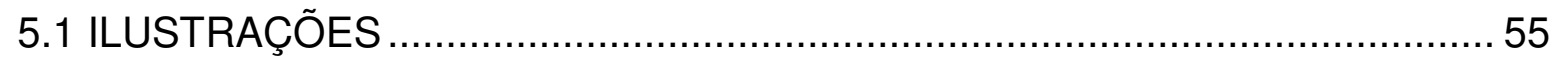

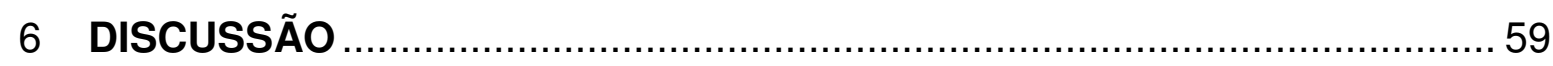

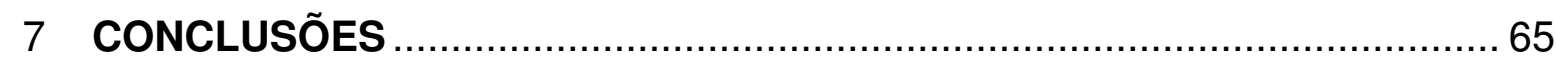

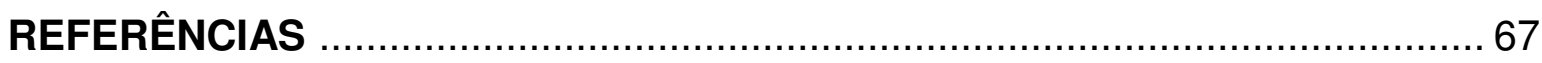




\section{INTRODUÇÃO}

O crescimento desordenado das grandes cidades contribui para a aproximação das áreas urbanas a regiões de habitat de certas aves, facilitando, algumas vezes, a busca por alguns exemplares como animais de estimação. Fato esse que obriga a medicina de aves a obter cada vez mais informações especializadas a respeito desses animais. São inúmeras as afecções que podem acometer as aves, e o trato digestório concentra grande parte dessas alterações.

A radiologia constitui-se em técnica essencial na medicina aviária que pode ser aplicada na avaliação dos transtornos musculoesqueléticos e nas enfermidades da cavidade celomática. O exame radiográfico é utilizado como método de auxílio diagnóstico de primeira escolha para triagem e, em alguns casos, possibilita até mesmo a conclusão diagnóstica. É considerado um dos exames complementares mais relevantes devido à possibilidade de ser realizado em pacientes de tamanhos distintos e interpretado rapidamente. É útil como técnica de investigação inicial e, também, como complemento de outras intervenções como endoscopia e na hematologia, auxiliando na conclusão do diagnóstico. A radiografia é útil na avaliação da evolução das enfermidades e na eficácia dos regimes terapêuticos. A radiologia pode ser considerada hoje como técnica segura e pouco invasiva, mesmo quando há necessidade de procedimentos anestésicos voláteis para o auxílio na contenção. Portanto, o exame radiográfico possibilita ao profissional evidenciar informações que, em conjunto com o exame clínico, são fundamentais para a definição do diagnóstico.

A pouca bibliografia específica disponível na área em tela, tem abordado o tema de forma genérica. Muitas são as espécies silvestres reconhecidas, e numerosas são as afeç̧ões, que muitas vezes são igualmente retratadas em diferentes espécies. Nestes casos, algumas delas deveriam que ser abordadas e tratadas individualmente de acordo com cada caso. 
A escassez de profissionais radiologistas e de rotina quanto à prática do exame radiográfico em aves é causada, principalmente, pela pouca intimidade com os métodos de contenção, técnica radiográfica, anatomia básica e interpretação da radiografia.

Assim, para um melhor auxílio no conhecimento no radiodiagnóstico das aves é necessário que haja trabalhos específicos para cada espécie e especialidade veterinária, para que esses animais, ainda pouco estudados, possam receber 0 tratamento necessário com precisão. 


\section{REVISÃO DE LITERATURA}

A classe filogenética das aves é formada por aproximadamente 9.700 espécies em todo mundo (SICK, 2001; BENEZ, 2004; O’MALLEY, 2005). Desse total, a fauna brasileira reúne 1.832 espécies (CBRO, 2011), das quais inúmeras são criadas em cativeiro, sendo em algumas as ocasiões sem finalidade econômica, como exemplo, a classe dos psitacídeos, que atualmente são as aves mais procuradas como animais de companhia (FORBES; LAWTON, 1996).

Os psitacídeos pertencem à ordem Psittacifomes e estão representados pelas araras, periquitos, papagaios e calopsitas. A causa pela qual essas espécies se popularizaram é o fato de possuírem como característica inteligência diferenciada (FORBES; LAWTON, 1996).

\subsection{ANATOMIA}

A anatomia das aves tem caráter diferenciado comparado a outras espécies animais.

Dentre os diferentes sistemas, ressalta-se o aparelho digestório, sendo o tubo digestório de cada ave adaptado para processar e utilizar o alimento disponível em seu habitat da forma mais eficaz possível (DUKE, 1996; POUGH; HEISER; McFARLAND, 1999). Essa capacidade evolutiva permitiu a sobrevivência das diversas populações de aves atuais, que criaram seus nichos ecológicos próprios de acordo com os recursos alimentares disponíveis (PETERSON, 1971).

A anatomia do sistema digestório dos psitacídeos possui diferenças quando comparado a outras espécies. Como características a ressaltar, observa-se que os Psittaciformes apresentam inglúvio e não apresentam cecos (Anexo A - figura 5). 
Entretanto, o tubo digestório em si apresenta poucas variações topográficas entre as espécies de psitacídeos (SANTOS et al., 2012).

O sistema digestório das aves Psittaciformes é composto pelo esôfago, estômagos (proventrículo e ventrículo), intestino delgado e intestino grosso (BENNETT; DEEM, 1996).

O esôfago é dividido em esôfago cervical, inglúvio e esôfago torácico. Os psitacídeos, como dito, estão entre as aves que possuem inglúvio - característica não compartilhada por todas as espécies de aves (SCHMIDT; REAVILL; PHALEN, 2003). O esôfago cervical e torácico são revestidos por epitélio escamoso espesso e estratificado. O esôfago cervical está ao lado direito do plano sagital mediano do pescoço (SCHMIDT; REAVILL; PHALEN, 2003), e é a parte mais longa, que segue dorsalmente à traquéia e retorna à linha mediana na porção cranial à entrada torácica (McLELLAND, 1986). Já a porção torácica, passa pela bifurcação da traquéia e a base do coração fundido-se com o estômago glandular (proventrículo) à esquerda do plano mediano (DYCE; SACK; WENSING, 1997). Abaixo do epitélio do esôfago existem glândulas produtoras de muco salivar que se assemelham às glândulas salivares (SCHMIDT; REAVILL; PHALEN, 2003)

O inglúvio é uma estrutura sacular que faz parte do esôfago, localizada na transição das porções cervical e torácica desse órgão, que tem capacidade de dilatar-se para se tornar altamente distensível (SCHMIDT; REAVILL; PHALEN, 2003) É responsável pelo armazenamento do alimento por curtos períodos de tempo, mais especificamente quando o estômago muscular (ventrículo) está repleto. É no inglúvio que ocorre a fermentação e embebição dos alimentos com mucosidades, preparando-os para a digestão gástrica posterior (MCLELLAND, 1986; DYCE; SACK; WENSING, 1997). Quando totalmente distendido, o inglúvio é quase transparente e varia em tamanho e forma de acordo com as espécies de aves.

O inglúvio do papagaio armazena alimento em um primeiro momento à direita e, posteriormente, à esquerda ultrapassando a linha mediana, podendo preencher a maior parte do espaço entre os ossos da clavícula. Em filhotes de 
papagaios é proporcionalmente maior do que em aves adultas (SCHMIDT; REAVILL; PHALEN, 2003).

O estômago nas aves é dividido em proventrículo (parte glandular) e ventrículo ou moela (parte muscular) (Anexo B - figura 6), localizados imediatamente seguidos um do outro no plano mediano (DYCE; SACK; WENSING, 1997). A anatomia do proventrículo e ventrículo varia consideravelmente entre espécies de aves. Nos psitacídeos, o proventrículo é um órgão espesso, de aspecto alongado e fusiforme, apresentando-se direcionado ventralmente à esquerda, situado no antímero esquerdo do assoalho da cavidade toracoabdominal (McLELLAND, 1986). Sua parede é composta predominantemente de glândulas tubulares. Estas glândulas contém uma única camada de células que produzem tanto pepsinogênio quanto ácido clorídrico (SCHMIDT; REAVILL; PHALEN, 2003).

O ventrículo é um órgão oco, arredondado (SCHWARZE, 1980), constituído por musculatura externa espessa, necessária para a trituração de alimentos ingeridos. (SCHMIDT; REAVILL; PHALEN, 2003). Pode-se dizer que este supre funcionalmente a ausência de dentes, por realizar a trituração do alimento prédigerido. (POUGH; HEISER; McFARLAND, 1999). Um tendão solto o cobre caudalmente. Histologicamente a musculatura do ventrículo contém três camadas de músculo liso, da qual a camada intermediária é a mais espessa. O tamanho do ventrículo não apenas varia de acordo com a espécie, mas também pode se alterar em qualquer ave quando aumenta-se o teor de fibra não digerível na dieta. Quantidades cada vez maiores de fibra resultam em um órgão dilatado. Isto deve ser considerado quando estudado o significado do tamanho ventricular na necropsia. A junção entre o proventrículo e o ventrículo é o istmo. Caracteriza-se por uma união muito curta onde há transição entre glândulas proventriculares e ventriculares. (SCHMIDT; REAVILL; PHALEN, 2003).

O intestino delgado é dividido anatomicamente em três segmentos duodeno, jejuno e íleo (McLELLAND, 1986). Possui como característica sua mucosa repleta de vilosidades (DUKE, 1996), onde ocorre a principal fase da digestão química (POUGH; HEISER; McFARLAND, 1999). Nos psitacídeos, o intestino delgado tem constituição relativamente simples. $O$ intestino do periquito, por 
exemplo, contem cinco segmentos de alças de intestino delgado antes de se tornar o cólon (intestino grosso), o que é considerado relativamente um intestino delgado curto.

A primeira porção do intestino é o duodeno. (SCHMIDT; REAVILL; PHALEN, 2003) Trata-se de alça constituída por porção descendente proximal e porção ascendente distal (McLELLAND, 1986), formando curva fechada disposta em "U" (NICKEL; SCHUMMER; SEIFERLE, 1977; DYCE; SACK; WENSING, 1997) e envolvendo o pâncreas. A maior parte da alça fica no assoalho abdominal e acompanha a curvatura caudal da moela (DYCE; SACK; WENSING, 1997). O início do jejuno é delimitado pela disposição distendida da porção final do intestino delgado em uma área onde termina a irrigação proveniente da artéria mesentérica cranial (SCHWARZE,1980). Ele é formado por diversas alças curtas, dispostas frouxamente, não unidas diretamente por mesentério (GADOW ${ }^{1}$, 1889 apud McLELLAND, 1986, p. 835). Duas porções mais curtas vêm a seguir. No terço médio da segunda porção encontra-se o resto do saco vitelino: o divertículo vitelino. É considerada a junção entre o jejuno e íleo (SCHMIDT; REAVILL; PHALEN, 2003), já que existe distinção histológica marcante entre jejuno e íleo (DUKE, 1996), embora isso seja de pouca importância fisiológica (SCHMIDT; REAVILL; PHALEN, 2003). O íleo é então composto de duas alças de semelhante comprimento (SCHMIDT; REAVILL; PHALEN, 2003).

Nas aves que não possuem cecos, como é o caso dos psitacídeos, o íleo é extensão do jejuno. Já em outras espécies, é localizado no centro da cavidade visceral, paralelamente às alças duodenais e está relacionado ao ventrículo, jejuno, reto e cecos (SCHWARZE, 1980).

O intestino grosso é o grande diferencial nos psitacídeos, pela já citada ausência de ceco. É composto basicamente por um intestino curto e reto, contínuo com íleo e cloaca (McLELLAND, 1986). O reto é um segmento curto, cuja função é acumular fezes (SCHWARZE, 1980).

\footnotetext{
${ }^{1} \mathrm{GADOW}, \mathrm{H}$. On the taxonomic value of the intestinal convolutions in birds. Proc. Zool.
} Soe. London, v. 21, p. 303-316, 1889. 


\subsection{EXAME RADIOGRÁFICO}

A prática da clínica aviária tem disponível variedade de exames complementares de diagnóstico por imagem, assim como nas espécies domésticas. À exemplo temos a radiologia, a ultrassonografia, a fluoroscopia, a tomografia computadorizada, a ressonância magnética e a cintilografia nuclear (MCMILLAN, 1994; RUPLEY, 1999). O exame radiográfico, no entanto, é o exame por imagem mais utilizado, justificado pelo custo-benefício positivo. Além de ser simples, nãoinvasivo, ter custo relativamente acessível e poder ser utilizado para diversas aplicações e sistemas (CRACKNELL, 2004). Ainda, considera-se que a radiologia das aves tem carater vantajoso quando comaprada com outras espécies, devido à presença difusa de ar dos sacos áereos, proporcionando contraste negativo para delimitar os órgãos da cavidade celomática (VINK-NOOTEBOOM; LUMEIJ; WOLVEKAMP, 2003). É importante que o exame radiográfico seja realizado sempre após uma detalhada avaliação clínica que inclua a anamnese, exame físico e os resultados de outros exames complementares, confirmando assim a necessidade da sua execução (PINTO, 2007), e diminuindo as chances de complicações durante o exame decorrentes ao estresse causado pela manipulação. Consequentemente, o exame radiográfico é contraindicado para pacientes em estado crítico, pois o estresse aumenta o risco de morte (SILVERMAN, 1987). Além disso, as aves comumente são levadas ao atendimento veterinário com enfermidades em estágio avançado de desenvolvimento, o que demanda, portanto, um diagnóstico rápido e preciso (KRAUTWALD-JUNGHANNS, 1996). Visando essa necessidade, o exame radiográfico é uma técnica diagnóstica viável por ser não-invasiva e de rápida interpretação (LAVIN, 1994).

Para a execução dos exames radiográficos em aves, utilizam-se equipamentos convencionais, os mesmos utilizados em animais domésticos (LAVIN, 1994). Em vista do tamanho geralmente pequeno das aves e da frequência respiratória alta, artefato de movimento pode ser evitado por meio da utilização de tempos curtos de exposição radiográfica (WILLIAMS, 2002; CRACKNELL, 2004). Em virtude do pequeno tamanho da maioria das aves, radiografias magnificadas são requeridas. Esta técnica é alcançada aumentando-se a distância entre o paciente e 
o chassi. Ferramentas espessas e radiotransparentes, como blocos de espuma, podem ser utilizadas para esta finalidade. O estudo radiográfico digital ou computadorizado são melhores recomendados para otimizar a interpretação radiográfica de pequenas estruturas. (WILLIAMS, 2002), pois os sistemas digitais são capazes de individualizar diferenças de atenuação muito pequenas entre as estruturas do corpo (BOCHMANN et al., 2011).

Sistemas de tela filmes convencionais ainda são as mais comumente utilizados para a radiografia aviária. Porém, é importante lembrar que existem sistemas de películas com filmes de alta resolução, tais como os filmes para mamografia, que são altamente recomendados, pois oferecem melhor resolução e um grande alcance dinâmico quando comparado ao filmes comuns (SMITH; SMITH, 1997; PEES, 2008). No entanto, é necessário usar um longo tempo de exposição, pois artefatos de movimento são frequentes (MCMILLAN, 1994; HARTUNG; LUDEWIG; TELLHELM, 2010)

\subsubsection{Métodos de exame radiográfico, posicionamento e contenção}

O posicionamento radiográfico é sem dúvida um dos pontos da técnica radiográfica de maior importância. Radiografias com posicionamentos inadequados podem apresentar distorção das imagens, o que pode induzir a interpretações errôneas ou inviabilizar a elaboração do diagnóstico radiográfico preciso (PINTO, 2007). O paciente deve ser posicionado diretamente em cima do chassi radiográfico (LAVIN, 1994; SMITH; SMITH, 1997; WILLIAMS, 2002). As aves podem ser posicionadas manualmente, indicado nos casos de aves tranquilas (WALSH, 1986), ou com a utilização de dispositivos de contenção (como exemplos: luvas de chumbo, fita adesiva ou objetos, tais como, blocos de espuma ou sacos de areia).

Dependendo das indicações para a radiografia, a condição e comportamento do paciente, a anestesia pode ser necessária ou contraindicada (VINKNOOTEBOOM; LUMEIJ; WOLVEKAMP, 2003). Pinto (2007) relata a necessidade 
de, sempre que possível, preconizar a contenção química dos pacientes, minimizando, assim, os erros de posicionamento, o stress do paciente e a exposição à radiação tanto do animal como das pessoas envolvidas. No entanto, o uso de sedação ou anestesia é desaconselhável quando o foco do estudo são os órgãos gastrointestimais e são necessários o uso de exames contrastados, devido a seu efeito negativo sobre a motilidade, dificultando a interpretação (KRAUTWALD et al., 1992; MCMILLAN, 1994).

Para a contenção manual, uma mão deve prender a cabeça da ave dorsalmente, mantendo a articulação da mandíbula entre polegar e dedo médio. A outra mão prende os pés e cuidadosamente estende os membros pélvicos. Para a projeção lateral, o pássaro é posicionado de lado com ambas as asas hiperestendidas sobre seu dorso. Para a projeção ventrodorsal, a ave é posicionada com o dorso diretamente sobre o chassi com as asas completamente estendidas para cada um dos lados do corpo (ISENBÜGEL; WOLVEKAMP; RÜBEL, 1991). O exame radiográfico adequado é aquele que permite a obtenção de pelo menos duas projeções em planos ortogonais (por exemplo, laterolateral e ventrodorsal) com a menor sobreposição possível de estruturas na área de interesse (PINTO, 2007). Deve-se evitar a sobreposição das asas e dos membros pélvicos na região da cavidade celomática, promovendo-se a extensão e a abdução dos mesmos. Deve-se ainda promover a sobreposição dos acetábulos e articulações escapulo-umerais na laterolateral e, na projeção ventrodorsal uma simetria da cavidade celomática através da sobreposição do esterno e da coluna vertebral (PINTO, 2007).

O conhecimento da anatomia radiográfica é imprescindível para a avaliação precisa das radiografias e é um dos elementos que mais dificulta a interpretação dos exames de animais selvagens, devido à grande variação anatômica existente entre os membros de cada classe de animais. O conhecimento da normalidade é imperativo para o reconhecimento das alterações radiográficas, devendo-se procurar assim, a comparação com imagens de livros, atlas, artigos ou com animais selecionados como clinicamente normais e que servem como base anatômica de referência (PINTO, 2007). 
No tocante à anatomia radiográfica do trato gastrointestinal das aves, podese dizer que:

O inglúvio é visualizado cranialmente à entrada do tórax, ventral e, algumas vezes, dorsalmente às vértebras cervicais na projeção laterolateral e à direita, ou até mesmo à esquerda, da linha média. É uma estrutura que apresenta desenvolvimento variável entre as aves, sendo mais desenvolvida nas espécies granívoras e onívoras (PINTO, 2007).

O esôfago torácico é normalmente visualizado no segmento em que se alarga para se unir com o proventrículo, na altura da base cardíaca, sendo este último melhor observado na projeção laterolateral como um formato elíptico ou em funil, dorsal ao fígado e cranial ao ventrículo (encurva-se ventralmente para se unir ao ventrículo) (PINTO, 2007).

Na projeção ventrodorsal, a margem lateral esquerda do proventrículo pode ser visualizada paralela à margem lateral esquerda do fígado, dando a falsa impressão de uma hepatomegalia (PINTO, 2007). Em radiografias laterais de pcitacideos, normalmente, o proventrículo e o ventrículo podem ser identificados (VINK-NOOTEBOOM; LUMEIJ; WOLVEKAMP, 2003). O ventrículo, por sua vez, é um órgão oval visualizado na projeção laterolateral na cavidade celomática ventral, caudal ao fígado, e na projeção ventrodorsal à esquerda da linha média, ao nível dos acetábulos. É um órgão facilmente identificado em aves que se alimentam de grãos ou de qualquer outro material radiopaco (por exemplo, fragmentos ósseos em aves carnívoras) (PINTO, 2007).

As porções intestinais localizam-se dorsalmente ao ventrículo na projeção ventrodorsal ocupando a parte caudal da cavidade celomática. Normalmente não se verifica a presença de gás no trato gastrointestinal das aves o que dificulta a identificação dos segmentos intestinais sem o uso de um contraste (PINTO, 2007). Para definição mais precisa entre os vários segmentos gastrointestinais, o exame contrastado com bário é frequentemente utilizado. No entanto, para este tipo de investigação são necessárias radiografias múltiplas, exigindo repetida manipulação do animal em estudo. Esta manipulação excessiva pode induzir ao estresse, resultando em efeitos imprevisíveis sobre a motilidade gastrointestinal. 
Radiografias sequenciais durante um exame com contraste gastrointestinal fornecem informações sobre a morfologia e permeabilidade do trato em si. No entanto, para a avaliação radiográfica da atividade peristáltica de diferentes segmentos, a imagem intensificada por fluoroscopia é melhor indicada (VINKNOOTEBOOM; LUMEIJ; WOLVEKAMP, 2003). A técnica de exame contrastado do trato gastrointestinal previamente recomendada segue a seguir.

Após submeter as aves por jejum de quatro horas, o meio de contraste é introduzido no inglúvio por meio de sondagem esofágica. Meios de contraste a base de sulfato de bário ou iodo podem ser utilizados. Alguns autores recomendam que a dosagem seja de 25 a $50 \mathrm{~mL} / \mathrm{kg}$ para o sulfato de bário, no entanto, a utilização de 10 a $15 \mathrm{~mL} / \mathrm{kg}$ é frequentemente suficiente e reduz o risco de regurgitação e aspiração. Quando houver necessidade da utilização de um contraste iodado, sugere-se o ioexol, $240 \mathrm{mgl} / \mathrm{mL}$ na mesma dosagem descrita anteriormente, para se obter um estudo seguro e eficaz $\mathrm{O}$ sulfato de bário, geralmente, proporciona um contraste positivo melhor e mais duradouro em comparação com produtos à base de iodo. Porém, é importante salientar que o bário pode causar irritação das vias respiratórias se acidentalmente aspirado e também deve ser evitado em casos de suspeita de perfuração gastrointestinal. A utilização do bário também impede qualquer cirurgia do TGI (por exemplo, para a biópsia de inglúvio), e só pode ser realizada quando o bário tiver sido completamente eliminado (PINTO, 2007).

O tempo de trânsito com sulfato de bário nas aves é de cerca de 2 horas e meia em psitacídeos médios e grandes, e de 30 a 240 minutos em pequenos psitacídeos, dependetemente da espécie estudada. Para a realização das exposições radiográficas sugere-se um intervalo de $30 \mathrm{~min}$ (em alguns casos é necessário realização de radiograficas nos tempos de 1, 2, 4, 8 e 24 horas após administração) (PINTO, 2007). Os tempos de visualização ideal das diferentes partes do trato gastrointestinal são listados no quadro 1. Em psitacídeos saudáveis, o sulfato de bário deve chegar à cloaca em até três horas após a administração, muitas vezes levando apenas alguns minutos para fazê-lo (SMITH; SMITH, 1997; MCMILLAN, 1999). O tempo de trânsito para os produtos à base de iodo não tem sido bem documentado, mas parece ser significativamente menor. 
Quadro 1 - Tempo ideal para individualização de órgãos após administração em $20 \mathrm{~mL} / \mathrm{kg}$ de suspensão sulfato de Bário 25\% em seis exemplares de Amazona aestiva

\begin{tabular}{|c|c|c|c|c|c|c|c|c|c|}
\hline & \multicolumn{7}{|c|}{ Tempo ideial para visualizaçao (minutos) } \\
\hline Órgão / local & $\mathbf{2}$ & $\mathbf{1 5}$ & $\mathbf{3 0}$ & $\mathbf{6 0}$ & $\mathbf{9 0}$ & $\mathbf{1 2 0}$ & $\mathbf{1 8 0}$ & $\mathbf{2 4 0}$ & $\mathbf{3 0 0}$ \\
\hline Inglúvio & $\mathrm{x}$ & $\mathrm{x}$ & $\mathrm{x}$ & & & & & & \\
\hline Proventrículo & & $\mathrm{x}$ & $\mathrm{x}$ & $\mathrm{x}$ & $\mathrm{x}$ & & & & \\
\hline Ventrículo & & $\mathrm{x}$ & $\mathrm{x}$ & $\mathrm{x}$ & $\mathrm{x}$ & $\mathrm{x}$ & & & \\
\hline Intestino & & & & $\mathrm{x}$ & $\mathrm{x}$ & $\mathrm{x}$ & $\mathrm{x}$ & & \\
\hline Colon & & & & & & $\mathrm{x}$ & $\mathrm{x}$ & $\mathrm{x}$ & \\
\hline Cloaca & & & & & & $\mathrm{x}$ & $\mathrm{x}$ & $\mathrm{x}$ & $\mathrm{x}$ \\
\hline
\end{tabular}

Fonte: (VINK-NOOTEBOOM; LUMEIJ; WOLVEKAMP, 2003).

Estudos contrastados podem ser realizados com o paciente anestesiado ou acordado, embora as desvantagens de anestesiar um animal doente sejam óbvias e múltiplas (aumento do risco anestésico, risco de aspiração, alteração da motilidade do TGl). O estudo contrastado fornece informações não só sobre o tamanho e o posicionamento relativo dos compartimentos gástricos, mas também sobre o tempo de trânsito gastrointestinal.

\subsection{AFECÇÕES DO PROVENTRÍCULO}

O estômago aviário desenvolveu-se graças à adaptação a um vasto leque de necessidades nutricionais. O proventrículo e o ventrículo desempenham papel crucial no fornecimento de um ambiente adequado para a redução física e química do tamanho e complexo molecular da dieta. O conhecimento adicional nesta área oferece ponto de partida valioso no entendimento da motilidade, da liberação de secreções gástricas e dos mecanismos de absorção deste órgão. Uma considerável variedade de doenças pode afetar o proventrículo, que é o órgão alvo das doenças mais encontradas nessas espécies. Seus sinais clínicos são frequentemente difíceis de diferenciar de doenças que afetam outras partes do trato gastrointestinal. É importante para o médico veterinário ter entendimento das condições que afetam o 
proventrículo para determinar procedimentos diagnósticos e terapêuticos apropriados (LANGLOIS, 2003).

\subsubsection{Afecções Neoplásicas}

Os papilomas de proventrículo são lesões incomuns e ocorrem com maior frequência em Araras sp particularmente na Arara vermelha. Estes animais geralmente têm lesões em esôfago e inglúvio e, frequentemente, apresentam como sintoma prostração crônica (SCHMIDT; REAVILL; PHALEN, 2003).

Os carcinomas de proventrículo podem afetar várias espécies de animais, mas em psitacídeos atingem com maior frequência os periquitos australianos, periquitos-de-bochecha-cinza e papagaios verdadeiros. Muitas vezes são encontrados na junção proventricular-ventricular, o que pode ser extremamente difícil de distinguir em alguns casos. Estas lesões são geralmente achatadas e regulares antes de se tornarem nodulares. Quando se estende pela superfície serosa, pode causar peritonite, deposição de fibrina e aderir ao fígado ou a outros órgãos. Se houver proliferação nodular no lúmen, é possível que cause hemorragia local associada à ulceração do tumor. As células neoplásicas tendem a formar agrupamentos infiltrativos, mas podem ser individualizadas. Há atividade mitótica moderada e proliferação de estroma. Estas células se infiltram pela musculatura e podem proliferar para a parede ventricular e pela camada serosa. A produção de estroma é variável. Esses tumores geralmente não induzem a metástases (SCHMIDT; REAVILL; PHALEN, 2003).

\subsubsection{Doenças não Infecciosas}

A causa mais comum das impactações gástricas em psitacídeos jovens é a ingestão de corpos estranhos, que pode causar até mesmo a perfuração do órgão. Animais afetados têm dilatação proventricular com parede flácida. A perfuração ou 
ruptura é caracterizada por hemorragia e acúmulo de alimento próximo da área afetada. Os animais com deficiência severa de vitamina A podem ter metaplasia das glândulas proventriculares, o que leva ao acúmulo excessivo de queratina, no qual deve ser diferenciada de cáseos, material resultante de inflamação/infecção (SCHMIDT; REAVILL; PHALEN, 2003).

A mineralização severa da mucosa do proventrículo é secundária à administração de cálcio dietético excessivo e também pode ocorrer em animais com ingestão excessiva de vitamina D3. As lesões podem não ser visíveis extremamente à necropsia, mas as glândulas proventriculares são afetadas histologicamente. Esta lesão parece ser mais comum em calopsitas e araras, particularmente na arara canindé (SCHMIDT; REAVILL; PHALEN, 2003).

\subsubsection{Doenças infecciosas}

As doenças infecciosas que afetam o proventrículo podem ter causas virais, bacterianas, micobacterianas, fúngicas e parasitárias (O'MEARA; WITTER, 1971; MORRISEY,1999).

Infecções bacterianas do proventrículo podem ser primárias ou secundárias. As infecções ocasionadas por bactérias gram-negativas se apresentam como lesões focais, com hiperemia difusa, necrose variável e hemorragia da mucosa. Pode haver presença de fibrina. Em casos severos, o proventrículo pode ser perfurado. É necessária a identificação do microrganismo para confirmação da etiologia específica (MORRISEY, 1999; SCHMIDT; REAVILL; PHALEN, 2003).

A presença de micobacteria já foi relatada em proventrículos de aves passeriformes e também em psitacídeos. A Micobacteriose do intestino delgado, é muito mais comum (SCHMIDT; REAVILL; PHALEN, 2003). Frequentemente são relatados achados de micobacterias na superfície mucosa do istmo de periquitos, canários, tentilhões e avestruzes. São organismos gram-positivos e relativamente grandes $(2 \times 20-40 \mu \mathrm{m})$. Elas são envelopadas, geralmente encontradas na 
superfície do istmo e frequentemente penetram abaixo das glândulas. Elas também podem afetar o ventrículo. A lesão agressiva primária associada com esta infecção provoca produção excessiva de muco. É de conhecimento coletivo dos clínicos que este organismo geralmente está associado com uma doença crônica debilitante. Deve-se lembrar, no entanto, que tantos os animais infectados como os assintomáticos têm lesões histológicas. Portanto, a presença deste organismo no achado de necropsia sem lesão aparente ou doença de histológica não é evidência conclusiva da causa morte da ave. Embora a presença de estresse antecedente seja necessária para que a infecção se torne clínica, a proventriculite por micobactéria é muitas vezes uma alteração somente encontrada no postmortem de animais doentes crônicos com severa perda de peso. Um leve infiltrado linfoplasmático também foi observado em exames do proventrículo de periquitos de isolamento, que eram livres deste organismo. Portanto, estas alterações não devem sempre ser atribuíveis a presença desse microorganismo (SCHMIDT; REAVILL; PHALEN, 2003).

Os fungos Zigomicetos causam proventriculite em várias espécies aviárias. As lesões visíveis são semelhantes às infecções bacterianas e a presença de úlceras é comum. Histologicamente há necrose e hemorragia, com uma resposta inflamatória pleomórfica e lesões fúngicas com formação de hifas intralesionais, que são vistas por toda a parede proventricular e dentro de vasos sanguíneos (MORRISEY, 1999; SCHMIDT; REAVILL; PHALEN, 2003).

A criptosporidiose do proventrículo é encontrada em grande variedade dos psitacídeos e pequenos passeriformes. Frequentemente nenhuma lesão é encontrada, mas é provável que cause produção excessiva de muco e hipertrofia variável de mucosa. A criptosporidiose é uma possível complicação de infecção da "doença do bico e das penas dos psitacídeos" (PBFDV) em cacatuas (MORRISEY, 1999; SCHMIDT; REAVILL; PHALEN, 2003).

Os espirurídeos, incluindo os Spiroptera sp. e Dyspharynx sp, podem parasitar o proventrículo. Eles exigem um artrópode hospedeiro intermediário e são, principalmente, observados em animais de vida livre. Em infestações pequenas, não há nenhuma alteração evidente e os parasitas são vistos histologicamente. Em infestações crônicas severas, a parede do proventrículo, particularmente a mucosa, 
se torna grosseira e o proventrículo pode estar distendido. A hemorragia é vista em casos severos e nematóides podem ser encontrados no lúmen. Fragmentos de parasita podem estar presentes na mucosa e no lúmen. A perfuração do proventrículo pode ocorrer, mas é incomum (MORRISEY, 1999; SCHMIDT; REAVILL; PHALEN, 2003).

\subsubsection{Doença da dilatação do proventrículo}

A principal doença a se considerar dentre as de origem viral é a Doença da Dilatação do Proventrículo (ou Proventricular Dilatation Disease, mundialmente conhecida como PDD). É uma doença infecciosa fatal que afeta, principalmente, o sistema nervoso central e periférico dos psitacídeos. É responsável pelos achados de lesões de grande importância mais comuns do proventrículo. A doença também foi chamada dilatação gástrica neuropática, ganglioneurite mioentérica, miosite proventricular e ventricular (SULLIVAN et al., 1997).

Tem como principal causa o Bornavírus, que é uma descoberta definitiva recente (HONKAVUORI et al., 2008; KISTLER et al., 2008), onde antes só existiam relatos de associação com Paramyxovirus, Herpesvirus, Circovirus e Picornavirus (LUBLIN et al., 2006). A etiologia viral para a doença foi suspeitada por muitos anos devido às evidências epidemiológicas e histopatológicas características observadas em tecidos das aves afetadas, mas nenhum vírus específico foi identificado, até a recente descoberta do Bornavirus aviário (GREGORY, 1996; HONKAVUORI et al., 2008; KISTLER et al., 2008). A PDD foi pela primeira vez descrita nos anos de 1970 em araras importadas por criadores dos EUA e da Alemanha. Caracterizada por má absorção ou má digestão, foi assim denominada "macaw wasting disease" ou "doença devastadora da arara" (LUBLIN et al., 2006).

Os Bornavírus são RNA vírus não codificados de fita simples e não segmentados da ordem dos Mononegavirales. Características únicas do genoma e do mecanismo de replicação do Bornavirus o classificaram em uma familia 
especifica (Bornaviridae), como exemplo, a replicação no núcleo da célula hospedeira ao em vez de no citoplasma (CUBITT; LY; DE LA TORRE, 2001; DE LA TORRE, 2006). O Bornavirus é um vírus envelopado, esférico, de tamanho médio e como a maioria dos vírus está na faixa tamanho de 70-130 nm (KOHNO et al.,1999).

A PDD tem sido relatada em mais de 70 espécies de psitacídeos (GREGORY, 1995; SHIVAPRASAD et al, 1995; REAVILL; SCHMIDT, 2007). Estas espécies incluem membros dos gêneros mais conhecidos, como da familia Psittacidae e famílias Cacatuidae, onde estão incluídas as Araras (Ara $s p)$, o Papagaio Cinzento Africano (Psittacus erithacus), as Cacatuas (Cacatua sp), os Papagaios em geral (Amazona sp), os Conures (por exemplo, Aratinga sp), e as Calopsitas (Nymphicus hollandicus). Apesar de frequentemente relatada em psitacídeos, também pode ocorrer em outras espécies de aves, como Falcões de cauda-vermelha, Gansos do Canadá, tucanos e no Colhereiro (GREGORY, 1995).

A epidemiologia da PDD na maioria das circunstâncias, tem a característica de se espalhar lentamente em surtos, afetando dezenas de aves durante um curto período de tempo (LUBLIN et al., 2006; KISTLER et al., 2008). Criadouros aviários lotados, bem como viveiros onde filhotes de papagaios são alimentados manualmente, parecem estar em maior risco. Embora a maioria dos casos notificados de PDD são em aves adultas, aves jovens a partir de cinco semanas podem ser afetadas (KISTLER et al., 2008). Animais com suspeita da doença, porém sem confirmação do diagnóstico devem ser isolados como medida preventiva (PARISI; CLUBB, 2010). É importante salientar que a infecção assintomática e de longo prazo que promove libertação do vírus também foi relatada e provavelmente desempenha um papel importante na epidemiologia da PDD (KISTLER et al., 2008; GANCZ et al., 2009). A via de transmissão da PDD ainda é desconhecida, mas acredita-se que seja de contágio feco-oral. Embora a compreensão da patogênese e epidemiologia ainda esteja em fase inicial, os estudos publicados até o presente momento fornecem comprovações diretas e indiretas de que o agente causador da PDD, o Bornavirus foi finalmente identificado (GANCZ; CLUBB; SHIVAPRASAD et al, 1995). O período de incubação de PDD parece ser extremamente variável. Sob condições experimentais, um estudo relatou um mínimo de 11 dias, (GREGORY et al., 1997) ao passo que noutros foi de aproximadamente um mês ou mais (GANCZ 
et al., 2009). O tempo máximo certamente está entre o intervalo de meses e, possivelmente, até mesmo de anos em alguns casos (GREGORY et al., 1997; GANCZ et al., 2009). As aves clinicamente afetadas por PDD além de poderem apresentar sintomas relacionados com o sistema digestório e neurológico, também podem ter morte súbita sem sintomas clínicos precedentes, como ocorre em alguns casos.

O acometimento entre os sexos é de carater variável. Em um determinado estudo as fêmeas foram relatadas apresentando casos de PDD numa proporção de 1:0,6 em relação aos machos, ao passo que em outro estudo os machos foram representados na proporção de 1:0,9 em relação as fêmeas (SHIVAPRASAD et al., 1995). Pouco se sabe sobre a ocorrência de PDD em populações de aves selvagens. Nenhum caso de PDD em animais de vida livre de qualquer continente foi relatado até o presente momento. A PDD é considerada a principal ameaça para as populações cativas de Arara azul (Cyanopsitta spixii) que são altamente ameaçadas, já que a espécie já está extinta na natureza (WYSS et al., 2009).

A PDD deve ser suspeitada em aves apresentando sintomas como: regurgitação intermitente, perda de peso (mesmo quando há apetite normal), depressão, diarréia, vômitos, anorexia, fezes com alimento não digerido e sinais neurológicos como, por exemplo, ataxia, confusão mental, movimentos involuntários da cabeça e déficit de propriocepção (GREGORY et al., 1998; LUBLIN et al., 2006). Frequentemente, os sinais clínicos são inespecíficos e refletem alterações em diferentes órgãos (ROSSKOPF, 2003; DE KLOET; DORRESTEIN, 2009). Quando associada ao quadro de megaesôfago, este pode induzir ao quadro de pneumonia aspirativa (MARIETTO-GONÇALVES, 2009). Muitos animais desenvolvem paralisia completa do íleo e de outros segmentos do aparelho digestório e, como resultado, ocorre emagrecimento progressivo notado pela ausência de tecido adiposo no postmortem. As lesões primárias vistas em PDD são flacidez e dilatação de qualquer porção do trato gastrointestinal, sendo o proventrículo, ventrículo e o inglúvio os órgão afetados com maior frequência. O proventrículo é considerado dilatado quando ocorre aumento que se estende ao lado esquerdo da cavidade celomática e desloca o ventrículo cranialmente à direita. Se a ave mantinha uma dieta de sementes, o proventrículo e ventrículo estarão repletos das mesmas. A atrofia dos 
músculos do ventrículo e diminuição da mucosa do proventrículo é comum. Também ocorre a ulceração multifocal da mucosa proventricular (GREGORY, 1995; BERHANE, 2001).

A dilatação de proventrículo em si não é patognomônica para PDD. Qualquer doença que cause obstrução parcial ou completa dos intestinos resultará em dilação proventricular. A dilatação proventricular é também uma lesão comum em gansos que são envenenados por chumbo (proventriculite tóxica). A obstrução do intestino delgado e o íleo paralítico também causam a dilatação deste órgão (DUSTAN, 1984; GELIS, 2006). Embora não seja frequentemente observada, a infecção por Poxvirus e a Doença de Pacheco podem resultar em lesões no proventrículo histologicamente semelhantes à PDD. Em estudo, foi demonstrado que o diâmetro proventricular sofre aumento ao longo do tempo em espécies de araras com PDD, e tem sido sugerida para ser um indicador útil para a realização de biópsia do inglúvio (WYSS et al., 2009). Outros compartimentos gastrintestinais também podem estar distendidos, e consequentemente passíveis de biópsia, tais como o ventrículo e o intestino delgado, no entanto, nenhum destes achados são específicos para PDD. $O$ grau de distensão das várias partes do TGI varia entre as aves com PDD, sendo que algumas alterações se mostram apenas no intestino ou no inglúvio (HOEFER, 1997; RITCHIE et al., 2004).

As aves com PDD podem mostrar, ou não, pequenas alterações no sangue, (GREGORY et al., 1994; HOEFER, 1997; BOUTETTE; TAYLOR, 2004). A anemia arregenerativa é a alteração hematológica mais comum vista na PDD. Este achado é semelhante ao que é visto em aves com anorexia ou jejum prolongado e está provavelmente relacionada com a má absorção gastrointestinal. A Leucocitose está presente em alguns pacientes com PDD, mas não é um achado consistente e parece estar relacionada com o estresse e/ou à existência de infecções secundárias. Do mesmo modo, as alterações bioquímicas observadas em aves com PDD são, principalmente, aquelas associadas com o estado catabólico. Proteína total e albumina estão eventualmente baixas (BOUTETTE; TAYLOR, 2004) e elevações ligeiras a moderadas de enzimas plasmáticas de origem muscular lactato desidrogenase (LDH), creatina quinase (CK), e aspartato aminotransferase (AST) podem ser vistas. Outras variações são possíveis, mas não são consistentes. Não 
obstante, realizar um painel bioquímico é importante para a exclusão de outras doenças para avaliar estado geral de saúde do animal. Também é aconselhável realizar testes para presença de chumbo e níveis de zinco no sangue de todas as aves com suspeita de PDD, pois os sintomas de intoxicação por metal pesado podem ser semelhantes àqueles de PDD. Em estudos anteriores, amostras positivas do Bornavirus foram confirmadas por meio de teste de PCR, e a sequência completa do genoma foi identificada, em dois estudos (HONKAVOURI et al., 2008; KISLER et al., 2008).

Atualmente, o procedimento diagnóstico mais recomendado para identificar casos de PDD é a biópsia do inglúvio. Embora a cirurgia e a anestesia possam apresentar riscos, tal procedimento é minimamente invasivo. Por meio da biópsia, o diagnóstico de PDD pode ser determinado através da identificação de alterações histológicas. As lesões histológicas são caracterizadas por um infiltrado linfoplasmocítico do plexo mioentérico em qualquer parte do esôfago, inglúvio ou outra área do trato gastrointestinal. Um infiltrado inflamatório também pode ser encontrado na camada muscular lisa. Histologicamente, observa-se uma leiomiosite linfocítica multifocal nos órgãos gastrointestinais, principalmente no proventrículo. (LYMAN, 1986; GREGORY et al., 1996; LUBLIN et al., 2006). A biópsia de inglúvio é relatada como um método eficaz de diagnóstico de antemortem em $76 \%$ dos animais afetados, quando fornecida amostra suficiente com um vaso sanguíneo visível. A amostragem de rotina na prática diagnóstica patologia foi menos eficaz em outro estudo (30\% a 35\% positivo) (SCHMIDT; REAVILL; PHALEN, 2003). Porém, alguns animais não apresentarão alterações evidentes no sistema digestório. Portanto, a biópsia do ingluvio pode ter resultado falso negativo devido ao fato de algumas aves terem lesões somente no cérebro ou em outras regiões do TGI. Devido a estas circunstâncias e, adicionalmente, ao fato de nem sempre se conseguir uma amostra de biópsia adequada, mesmo quando o tecido pesquisado foi afetado histologicamente, a PDD não pode ser descartada com base em um resultado negativo de biópsia do inglúvio ou de outra parte do trato gastrointestinal (PARISI; CLUBB, 2010).

As técnicas diagnósticas de imagem, tais como o exame radiográfico, a radiografia contrastada, a fluoroscopia e a ultrassonografia são assistentes úteis no 
auxílio diagnóstico de PDD, mas não podem ser usados como únicos meios para confirmá-la ou descartá-la (HOEFER, 1997; LUMEIJ, 1999).

Para casos onde se suspeita de PDD, a radiografia simples da cavidade celomática é o diagnóstico por imagem mais viável, por fornecer informação suficiente para a avaliação do tamanho dos compartimentos do TGI. O achado radiográfico mais consistente nos animais com PDD é a dilatação variável do proventrículo que contém principalmente conteúdo alimentar radiopaco e quantidades variáveis de gás (WYSS et al, 2009) (Figuras 1, 3 e 4). Porém, exemplos de distenção sem significancia clínca já foram relatados. Um proventrículo relativamente grande já foi visto em alguns exemplares saudáveis de papagaioecletus, assim como a distensão do proventrículo e do inglúvio pode ser fisiológica em aves recém-nascidas (HOEFER, 1997; RITCHIE et al., 2004).

Nos casos em que os resultados são ambíguos ou quando o quadro clínico não se encaixa bem com PDD, estudos radiográficos com contraste positivo podem ser indicados. A técnica adequada para a realização deste tipo de estudo em psitacídeos foi anteriormente descrita (SMITH; SMITH, 1997; MCMILLAN, 1999). Em alguns animais afetados com PDD o tempo de trânsito pode ser bem prolongado, (GREGORY et al., 1994; HOEFER, 1997) enquanto em outros é normal ou até mesmo reduzido. Tempo de trânsito Gl pode ser alterado por muitas condições patológicas e fisiológicas; por conseguinte, o tempo de trânsito gastrointestinal não pode ser considerado um indicador sensível ou específico da presença de PDD.

Recentemente, descreveu-se estudo analisando radiograficamente a relação entre o proventrículo e a quilha como um método altamente sensível e específico com o objetivo determinar o tamanho do proventrículo anormal em psitacídeos. Nesse estudo, animais comprovadamente com dilatação proventricular (confirmados por necropsia posterior) foram estudados através de radiografia lateral direita, sob anestesia geral, após pelo menos 1 hora de jejum. O diâmetro do proventrículo foi medido a partir da silhueta das serosas, no eixo perpendicular do proventrículo, na altura da transição da última vértebra torácica com o sinsacro. A altura da quilha foi medida imediatamente caudal sobreposição da margem distal do osso coracóide sobre o esterno, perpendicular à margem dorsal do esterno. A relação entre eles foi 
calculada dividindo-se o tamanho do proventrículo pelo tamanho da quilha. Quando o valor desta relação for <0,48, considera-se dentro dos limites da normalidade, enquanto que o valor de relação $>0,52$ é compatível com doença proventricular que promova a dilatação do mesmo. Esse mesmo estudo sugere este como um método eficaz para determinar a dilatação, porém não é útil como avaliação prognóstica (BOUTETTE; TAYLOR, 2004; DE LA TORRE, 2006).

A fluoroscopia pode também auxiliar o diagnóstico de PDD (BOUTETTE; TAYLOR, 2004). O procedimento é realizado com da administração por sonda esofágica de 5 a $10 \mathrm{~mL} / \mathrm{kg}$ de sulfato de bário misturado na concretração de 1:1 com alimentação comercial, a ave é submetida à observação intermitentemente com o fluroscópio, até que o bário atinja sua cloaca. A principal vantagem da fluoroscopia quando comparada com os estudos contrastados, é que ela fornece em tempo real vistas da motilidade gastrointestinal. Obviamente é necessário saber os padrões normais de motilidade, para a detecção de alterações. Em psitacideos normais, o bolus ingerido pode ser claramente visto a partir do inglúvio e evolui ao longo esôfago torácico para o proventrículo. Este bolus normalmente ocorre em uma taxa aproximada de um bolus por minuto e deve ser unidirecional sem quantidade significativa de bário restante no esôfago entre os bolus. A motilidade do proventrículo é menor do que a de outras partes do TGI, mas em poucos minutos uma grande contração seguida de esvaziamento parcial do ventrículo deve ser vista. Pouca ou nenhuma motilidade proventricular pode estar presente em pacientes com PDD com um proventrículo grosseiramente distendido. A visualização mais impressionante é dada pelas mudanças na motilidade do ventrículo com PDD. Devido à contração sequenciada dos pares musculares da sua parede, um efeito de rotação constante é produzida, e deve ser claramente visível na projeção lateral de uma ave saudável. Em pacientes com PDD este padrão pode ser completamente ausente, sendo muitas vezes substituído por uma turbulência superficial e irregular da parede do ventrículo.

A causa provável de falha de trituração mecânica dos alimentos, que leva ao achado de sementes inteiras nas fezes de pacientes com PDD, é a alteração no peristaltismo do intestino delgado, que normalmente deve ser bidirecional em psitacídeos, com evolução fecal até certa porção intestino grosso e após, volta para 
o piloro. Alguns pacientes com PDD podem mostrar por meio da fluroscopia uma rápida e irregular atividade peristáltica e um aumento no diâmetro do duodeno, enquanto que em outros, a motilidade pode ser mais lenta do que normal. Como em outras técnicas de imagem, os resultados da fluoroscopia devem ser considerados sugestivos, mas não confirmam a PDD. Infelizmente, esta técnica requer equipamentos caros e, portanto, não é facilmente disponível para muitos médicos veterinários (GANCZ; CLUBB; SHIVAPRASA, 2010).

O tratamento para PDD não é considerado totalmente eficaz, porém relata-se que o uso de antiinflamatórios não-esteroidais, associados à administração de alimentos líquidos/pastosos por meio de sonda esofágica resulta em melhora no quadro clínico (LUBLIN et al., 2006). Embora considerada fatal, quando realizado diagnóstico e tratamento precoce da PDD, a sobrevivência e qualidade de vida da ave podem ser melhoradas. Foi sugerido que 0 tratamento com agentes antiinflamatórios cyclooxygenase-2 pode diminuir a inflamação associada à PDD com resposta favorável ao tratamento. O esquema de tratamento usado com êxito é relatado com uma combinação de Celecoxib $^{2}$ e um medicamento antiviral, Hydrochloride de Amantadine ${ }^{3}$ (CARPENTER; MASHIMA; RUPPIER, 2005).

\footnotetext{
${ }^{2}$ Dose: 20 mg/Kg VO, SID; Celebrex®; Pfizer Corp, Nova lorque, NY, EUA

${ }^{3}$ Dose: 10 mg/Kg VO, SID; Symmetrel®; Faixa Pharmacaps Inc, Alto Ponto, NC, EUA
} 


\section{OBJETIVO}

O objetivo do estudo retrospectivo foi de analisar exames radiográficos de aves psittaciformes encaminhadas ao Serviço de Diagnóstico por Imagem do Departamento de Cirurgia ( $\mathrm{VCl}$ ) da Faculdade de Medicina Veterinária e Zootecnia da Universidade de São Paulo (FMVZ-USP), no período de janeiro de 2004 a abril de 2012, visando:

- contribuir com o estudo das principais alterações radiográficas ao exame simples

e contrastado que acometem o trato digestório dos psitacídeos especificamente àquelas associadas ao proventrículo.

- estabelecer a distribuição da frequência segundo a espécie e idade. 


\section{MATERIAL E MÉTODO}

O presente estudo retrospectivo foi aprovado pela Comissão de Ética no Uso de Animais (CEUA) da Faculdade de Medicina Veterinária e Zootecnia da Universidade de São Paulo (FMVZ-USP) com o protocolo no $2311 / 2011$, em 15/08/2012. Este estudo compreendeu o levantamento radiográfico para a avaliação da casuística de afecções no proventrículo detectadas por achados no exame radiográfico, citados aos laudos, das aves atendidas no Ambulatório de Aves do Departamento de Patologia junto ao Hospital Veterinário da FMVZ-USP no período de Janeiro de 2004 a Abril de 2012 e disponíveis nos arquivos do Serviço de Diagnóstico por Imagem do Departamento de Cirurgia da FMVZ-USP, para a determinação dos padrões radiográficos das afecções do proventrículo mais comumente encontradas.

As imagens radiográficas dos animais foram disponibilizadas pelo Serviço de Diagnóstico por Imagem do Departamento de Cirurgia junto ao Hospital Veterinário da FMVZ-USP.

\subsection{EXAME RADIOGRÁFICO}

\subsubsection{Equipamentos radiográficos}

Os exames radiográficos foram realizados em aparelhos de radiodiagnóstico convencionais ${ }^{4}$, com ampola de raios- $X$ de ânodo giratório.

Os exames realizados entre Janeiro/2004 e Outubro/2009 utilizaram-se metodologia convencional com chassis, que possuíam telas intensificadoras ${ }^{5} \mathrm{e}$

\footnotetext{
${ }^{4}$ marca CGR, de $600 \mathrm{mAs}$ e $130 \mathrm{kV}$, modelo Chenonceaux, e marca RAY TEC, de $500 \mathrm{~mA}$ e $125 \mathrm{kV}$, modelo RT - 500/125.

${ }^{5}$ Kodak Lanex Regular Screens, Eastman Kodak Company.
} 
filmes radiográficos ${ }^{6}$ revelados e fixados em processadora automática ${ }^{7}$, após identificação luminosa com os dados do animal. Todos os exames radiográficos foram realizados respeitando-se as normas de proteção radiológica. Já os exames datados de Novembro/2009 a Abril/ 2012 foram obtidos através de equipamento digitalizador de imagens $^{8}$, e chassis especiais que continham Placa flexível de fósforo fotoestimulável (cristais de bário contendo íons de Europium), denominada pelo fabricante como "Imaging Plate, ou IP", que foi então utilizada no lugar dos filmes de raios- $X$, que é a responsável por armazenar os dados, transmitir à leitora $e$ consequentemente ao computador.

\subsubsection{Métodos de contenção}

O principal método de contenção utilizado foi o manual, com o auxílio dos proprietários e técnicos de radiologia.

\subsubsection{Posicionamentos radiográficos}

Os animais foram posicionados diretamente sobre o chassi/cassete radiográfico. Foram realizadas radiografias de corpo inteiro, em decúbito lateral direito (para projeção laterolateral direita) ou decúbito lateral esquerdo (para projeção laterolateral esquerda), e em decúbito dorsal, no caso da projeção ventrodorsal.

\footnotetext{
${ }^{6}$ T-MAT G/RA e MXG/Plus, Kodak Brasileira Com. Ind. Ltda.

${ }^{7}$ RP X-OMAT Processor, Eastman Kodak Company.

${ }^{8}$ Fujifilm FCR Capsula XLII.
} 


\subsubsection{Técnicas radiográficas}

As técnicas radiográficas utilizadas basearam-se no método que relaciona a quilovoltagem e a miliamperagem segundo com a espessura da região a ser radiografada.

Em 10 dos casos estudados foi realizada a técnica contrastada do trato gastrointestinal, através da administração de meio de contraste à base de sulfato de bário $^{9}$ na concentração de 100\%, na dose recomendada em literatura de $25 \mathrm{ml} / \mathrm{kg}$, com realização de imagens sob intervalos médios de 30 minutos variando em cada estudo entre 0 minutos a 24 horas (de acordo com os achados radiográficos e 0 tempo total do transito gastrointestinal em cada animal), após administração do meio de contraste.

\subsection{ANÁLISE DAS RADIOGRAFIAS E LAUDOS RADIOGRÁFICOS}

Cada exame radiográfico foi particularmente analisado, juntamente com o laudo radiográfico, observando-se todas as alterações radiográficas encontradas na cavidade celomática, com ênfase no proventrículo. Os animais que fizeram parte do estudo foram selecionados quando apresentavam algum tipo de alteração em proventrículo descritas ao laudo radiográfico. $\mathrm{Na}$ triagem dos casos a serem estudados, houveram alguns animais que não foram encontradas as imagens radiográficas e outros ainda os prontuário com dados clínicos não foram localizados. Nestes casos foram então excluídos do estudo.

\footnotetext{
${ }^{9}$ Bariogel $100 \%$ Cristalia ${ }^{\circledR}$
} 


\subsection{ANÁLISE DOS PRONTUÁRIOS}

Foram retiradas e analisadas dados de resenha e informações das fichas clínicas contidas nos prontuários dos animais selecionados que apresentavam alterações em proventrículo descritas ao laudo radiográfico.

As manifestações clínicas descritas variaram entre alterações relacionadas ao trato gastrointestinal, sistema neurológico e do estado geral dos animais.

\subsection{ANÁLISE ESTATÍSTICA}

Os resultados obtidos foram expressos mediante a distribuição numérica e percentual e apresentados sob a forma de tabelas e quadros. Em situações consideradas pertinentes, utilizou-se o Teste Qui-Quadrado, com nível de significância de $p<0,05$ ( $\alpha=5 \%)$, com a finalidade de comparar se a proporção de respostas entre duas ou mais determinadas variáveis e/ou seus níveis é estatisticamente significante.

A concordância entre suspeita de PDD na avaliação clínica e sugerido pelo laudo radiográfico foi testada mediante a obtenção do coeficiente Kappa (para variáveis categóricas).

\subsection{DOCUMENTAÇÃO FOTOGRÁFICA}

Foram selecionadas algumas radiografias para a documentação fotográfica, com o desígnio de ilustrar a extensa variedade de alterações radiográficas encontradas no trato gastrointestinal das aves. 


\section{RESULTADOS}

A análise das alterações radiográficas permitiu o auxilio diagnóstico das afecções no PV e TGI.

Foram analisados exames radiográficos de 38 aves nacionais e exóticas, listadas na tabela 1, na qual esmiúça a classificação das aves segundo sua ordem, família, nome científico e nome comum.

Já a tabela 2 refere-se aos sinais clínicos apresentados e sua distribuição numérica, tal como na tabela 3 , onde se filtra dentre os mesmo animais e seus sintomas apenas indivíduos nos quais foram utilizados método de exame radiográfico contrastado.

A tabela 4 demonstra às suspeitas clínicas mais frequentemente citadas nos prontuários de atendimento clínico. Assim também, a tabela 5 filtra dentre os mesmos animais apenas aqueles onde optou-se por exame radiográfico contrastado.

A tabela 6 cita a distribuição de acordo com a evolução e histórico nos prontuários de atendimento clínico, e analisa numericamente os casos onde houve melhora, piora ou ausência de retorno ao atendimento.

A tabela 7 relata a distribuição numérica de acordo com exames complementares solicitados.

A tabela 8 descreve os achados radiográficos encontrados aos laudos, assim como a tabela 9, que filtra dentre os mesmo animais somente aqueles com exame contrastado.

A tabela 10 lista a frequência de suspeita clínica de acordo com as espécies em estudo. Já a tabela 11 correlaciona a frequência de suspeita clínica com a idade dos animais. 
A tabela 12 descreve as aves nas quais havia suspeita de PDD, tanto ao laudo radiográfico quanto na suspeita clínica, e analisa os casos em que foi optado pelo exame contrastado.

A tabela 13 correlaciona as suspeitas clínicas com os achados radiográficos citados. Já a tabela 14 cruza os sintomas e os achados radiográficos.

Tabela 1 - Distribuição com as frequências absolutas (N) e relativas (\%) de 38 aves, selecionadas com alteração em proventrículo ao laudo radiográfico, segundo a taxonomia - HOVETFMVZ-USP - 2004-2012

\begin{tabular}{|c|c|c|c|c|c|}
\hline ORDEM & FAMILIA & $\begin{array}{c}\text { NOME } \\
\text { CIENTíFICO }\end{array}$ & NOME COMUM & $\mathbf{N}$ & $\%$ \\
\hline \multirow[t]{10}{*}{ PSITTACIFORMES } & Cacatuidae & $\begin{array}{l}\text { Nymphicus } \\
\text { hollandicus }\end{array}$ & Calopsita & 11 & 28,9 \\
\hline & Psittacidae & $\begin{array}{c}\text { Amazona } \\
\text { aestiva }\end{array}$ & Papagaio-verdadeiro & 17 & 44,8 \\
\hline & & $\begin{array}{c}\text { Ara } \\
\text { chloroptera }\end{array}$ & Arara-vermelha & 1 & 2,6 \\
\hline & & Ara ararauna & Arara-Canindé & 1 & 2,6 \\
\hline & & $\begin{array}{c}\text { Amazona } \\
\text { rhodocorytha }\end{array}$ & Chauá & 1 & 2,6 \\
\hline & & $\begin{array}{l}\text { Psittacus } \\
\text { erithacus }\end{array}$ & Papagaio-do-congo & 1 & 2,6 \\
\hline & & $\begin{array}{c}\text { Polytelis } \\
\text { anthopeplus }\end{array}$ & Regente & 1 & 2,6 \\
\hline & & $\begin{array}{c}\text { Amazona } \\
\text { vinacea }\end{array}$ & $\begin{array}{l}\text { Papagaio-de-peito- } \\
\text { roxo }\end{array}$ & 2 & 5,3 \\
\hline & & $\begin{array}{l}\text { Pyrrhura } \\
\text { frontalis }\end{array}$ & $\begin{array}{c}\text { Tiriba-De-Testa- } \\
\text { Vermelha }\end{array}$ & 1 & 2,6 \\
\hline & & $\begin{array}{l}\text { Amazona } \\
\text { amazonica }\end{array}$ & $\begin{array}{l}\text { Papagaio-do- } \\
\text { mangue }\end{array}$ & 2 & 5,4 \\
\hline TOTAL & & & & 38 & 100 \\
\hline
\end{tabular}


Tabela 2 - Distribuição da frequência absoluta $(\mathrm{N})$ e relativa $(\%)$ das manifestações clínicas de 38 aves selecionadas com alteração em proventrículo ao laudo radiográfico, de acordo com sintomas apresentados - HOVET-FMVZ-USP - 2004-2012

\begin{tabular}{ccc}
\hline SINTOMA & N & $\%$ \\
\hline Anorexia / Hiporexia & 20 & 52,63 \\
Emese / Regurgitação & 15 & 39,47 \\
Polidipsia & 5 & 13,16 \\
Diarréia & 9 & 23,68 \\
Prostração / Apatia & 20 & 52,63 \\
Emagrecimento / Caquexia & 12 & 31,58 \\
Incoordenação / Convulsão / Sinais Neurológicos & 6 & 15,79 \\
Dilatação / conteúdo em Inglúvio & 5 & 13,16 \\
Fezes Enegrecidas & 5 & 13,16 \\
Fezes Com Alimento Não Digerido & 2 & 5,26 \\
Fezes Esverdeadas & 7 & 18,42 \\
Aumento Volume Abdominal & 3 & 7,89 \\
Poliúria & 6 & 15,79 \\
Hipotermia & 1 & 2,63 \\
Disquesia / Constipação & 2 & 5,26 \\
Adipsia / Hipodipsia & 3 & 7,89 \\
Desidratação & 3 & 7,89 \\
Secreção nasal / espirros / estertor & 5 & 13,16 \\
Distrição respiratória & 3 & 7,89 \\
\hline
\end{tabular}

Os sintomas de maior frequência foram a anorexia/hiporexia, emese/regurgitação, prostração/apatia $(p<0,0001)$ (ordem 1), existindo portanto diferença estatística significativa entre as frequências, quando comparada com os demais sintomas. Seguidos estão: diarreia, emagrecimento/ caquexia, incoordenação / convulsão / sinais neurológicos, fezes esverdeadas e poliúria (ordem 2).Os demais sintomas apresentaram a mesma frequência $(p>0,05)$ (ordem 3).

Tabela 3 - Frequência absoluta $(\mathrm{N})$ e relativa $(\%)$ de 10 aves com exame radiográfico contrastado, dentre as 38 aves estudadas com alteração no proventrículo ao laudo radiográfico, de acordo com sintomas apresentados - HOVET-FMVZ-USP - 2004-2012

\begin{tabular}{lcc}
\hline \multicolumn{1}{c}{ SINTOMA } & N & $\%$ \\
\hline Emese / Regurgitação & 6 & 60,00 \\
Alteração em fezes & 7 & 70,00 \\
Alteração no consumo da alimentação & 4 & 40,00 \\
Prostração / apatia & 6 & 60,00 \\
Alteração no consumo de líquido & 3 & 30,00 \\
Anemia & 2 & 20,00 \\
Incoordenação / sinais neurológicos & 1 & 10,00 \\
Poliúria & 1 & 10,00 \\
Desidratação & 2 & 20,00 \\
Emagrecimento & 2 & 20,00 \\
Secreção nasal & 1 & 10,00 \\
\hline
\end{tabular}


Os sintomas apresentados pelas aves submetidas ao exame radiográfico contrastado de maior frequência foram: Alteração em fezes, emese/regurgitação, prostração/apatia (ordem 1), existindo assim diferença estatística significativa entre as frequências $(p<0,0001)$, quando comparada com os demais sintomas.

Seguidamente estão a alteração no consumo de alimentação e alteração no consumo de líquido $(p=0,0004)$ (ordem 2). Os demais sintomas apresentaram a mesma frequência $(p>0,05)$ (ordem 3$)$.

Tabela 4 - Frequência absoluta $(\mathrm{N})$ e relativa (\%)de 38 aves estudadas com alteração no proventrículo ao laudo radiográfico, de acordo com a suspeita clínica - HOVET-FMVZUSP - 2004-2012

\begin{tabular}{lcc}
\hline \multicolumn{1}{c}{ Suspeita clínica } & N & $\%$ \\
\hline Prostração a esclarecer & 3 & 7,89 \\
PDD & 10 & 26,32 \\
Gastrenterite / Enterite & 7 & 18,42 \\
Corpo Estranho / intoxicação & 3 & 7,89 \\
Má absorção & 2 & 5,26 \\
\hline Ascite & 1 & 2,63 \\
Agente Infeccioso do TGI & 7 & 18,42 \\
Pneumonia / Aerosaculite & 4 & 10,53 \\
Incoordenação / Convulsão & 2 & 5,26 \\
\hline Alteração no baço & 1 & 2,63 \\
Pancreatite / insuficiência pancreática & 2 & 5,26 \\
\hline Sem suspeita clínica conclusiva & 7 & 18,42 \\
Deficiência nutricional & 2 & 5,26 \\
\hline Alterações ósseas & 1 & 2,63 \\
\hline
\end{tabular}

As suspeitas clínicas de PDD, gastrenterite / enterite, agente Infeccioso do TGI e casos sem suspeita clínica conclusiva apresentaram as maiores frequências $(p=0,0001)$, existindo assim diferença estatística significativa entre as frequências, quando comparada com as demais suspeitas. 
Tabela 5 - Frequência absoluta $(\mathrm{N})$ e relativa (\%) de 10 aves com exame radiográfico contrastado, dentre as 38 aves estudadas com alteração no proventrículo ao laudo radiográfico, de acordo com a suspeita clínica - HOVET-FMVZ-USP - 2004-2012

\begin{tabular}{lcc}
\hline \multicolumn{1}{c}{ Suspeita clínica } & N & $\%$ \\
\hline Alterações no TGI & 4 & 40,00 \\
Alteração neurológica & 1 & 10,00 \\
Prostração a esclarecer & 2 & 20,00 \\
Aerosaculite & 2 & 20,00 \\
Corpo estranho & 1 & 10,00 \\
Alteração pancreática & 1 & 10,00 \\
PDD & 2 & 20,00 \\
Processo infeccioso do TGI & 1 & 10,00 \\
\hline
\end{tabular}

As suspeitas clínicas de alterações no TGI, apresentaram as maiores frequências $(p=0,0001)$, portanto existe diferença estatística significativa entre as frequências, quando comparada com as demais suspeitas.

Tabela 6 - Frequência absoluta $(\mathrm{N})$ e relativa (\%) de 38 aves estudadas com alteração no proventrículo ao laudo radiográfico, de acordo com a evolução dos históricos em prontuários - HOVET-FMVZ-USP - 2004-2012

\begin{tabular}{lcc}
\hline \multicolumn{1}{c}{ Evolução } & N & $\%$ \\
\hline Melhora & 9 & 23,68 \\
Piora / óbito & 7 & 18,42 \\
Sem retorno & 22 & 57,89 \\
Total & 38 & 100,00 \\
\hline
\end{tabular}

Os casos sem retorno, apresentaram as maiores frequências $(p=0,0001)$ (ordem 1), existindo assim diferença estatística significativa entre as frequências $(p<0,0001)$, quando comparada com as demais evoluções. 
Tabela 7 - Frequência absoluta $(\mathrm{N})$ e relativa (\%) dos exames complementares solicitados (além do exame radiográfico simples) de 38 aves estudadas com alteração no proventrículo ao laudo radiográfico de acordo com a modalidade solicitada - HOVET-FMVZ-USP 2004-2012

\begin{tabular}{ccc}
\hline EXAME COMPLEMENTAR & $\mathbf{N}$ & $\%$ \\
\hline RX CONTRASTADO & 10 & 26,32 \\
HEMOGRAMA & 8 & 21,05 \\
BIOQUIMICO & 5 & 13,16 \\
ENDOSCOPIA & 3 & 7,89 \\
PCR CLAMAMIDIA & 4 & 10,53 \\
GRAM FEZES & 8 & 21,05 \\
COPROPARASITOLOGICO & 5 & 13,16 \\
HISTOPATOLOGICO / BIÓPSIA & 3 & 7,89 \\
NECROPSIA & 3 & 7,89 \\
ULTRASSONOGRAFIA & 1 & 2,63 \\
\hline
\end{tabular}

Os exames de radiografia contrastada, hemograma e gram de fezes, apresentaram as maiores frequências $(p=0,0001)$ (ordem 1), existindo assim diferença estatística significativa entre as frequências $(p<0,0001)$, quando comparada com os demais exames.

Tabela 8 - Frequência absoluta $(\mathrm{N})$ e relativa (\%) de 38 aves com alterações no proventrículo descritas ao laudo radiográfico, segundo os achados radiográficos - HOVET-FMVZUSP - 2004-2012

\begin{tabular}{ccc}
\hline ACHADO RADIOGRÁFICO & N & $\%$ \\
\hline Dilatação do proventrículo por gás e líquido & 13 & 34,21 \\
Aumento do proventrículo por gás & 8 & 21,05 \\
Dilatação do proventrículo por conteúdo líquido & 10 & 26,32 \\
Homogeneidade topografia de alças & 10 & 26,32 \\
Conteúdo líquido em alças intestinais & 2 & 5,26 \\
Dilatação de alças intestinais & 5 & 13,16 \\
Distensão abdominal difusa & 6 & 15,79 \\
Alterações no ventrículo & 6 & 15,79 \\
\hline
\end{tabular}

O achado radiográfico "dilatação do proventrículo por gás e líquido" (Figura 1 - A e B) apresentou a maior frequência $(p=0,0001)$ (ordem 1), existindo diferença estatística significativa $(p<0,0001)$ quando comparada com os demais achados. Seguidas estão as alterações radiográficas de ordem 2: "aumento do proventrículo por gás", dilatação do proventrículo por conteúdo líquido, espessamento de paredes 
$\mathrm{PV}$, homogeneidade topografia de alças, dilatação de alças intestinais, distensão abdominal difusa, alterações no ventrículo e retenção do meio de contraste ou evolução lenta.

As demais alterações radiográficas apresentaram a mesma frequência $(p>0,05)$ (ordem 3).

Tabela 9 - Frequência absoluta $(\mathrm{N})$ e relativa (\%) segundo as achados radiográficos aos exames contrastados de 10 aves, dentre as 38 aves estudadas com alteração no proventrículo ao laudo radiográfico - HOVET-FMVZ-USP - 2004-2012

\begin{tabular}{lcc}
\hline \multicolumn{1}{c}{ Aspectos radiográficos observados } & N & $\%$ \\
\hline Retenção do meio de contraste ou evolução lenta & 5 & 50,00 \\
Espessamento de parede em PV ou Ventrículo & 5 & 50,00 \\
Dilatação do proventrículo (gás e/ou contraste) & 4 & 40,00 \\
Falhas de preenchimento em PV & 4 & 40,00 \\
Alteração / Dilatação de alças intestinais & 3 & 30,00 \\
Alteração no ventrículo & 2 & 20,00 \\
\hline
\end{tabular}

Os achados radiográficos: "retenção do meio de contraste ou evolução lenta" (figura 2), "espessamento de parede em PV ou ventrículo" e "dilatação do proventrículo (gás e/ou contraste)", apresentaram as maiores frequências ( $p=0,0014)$ (ordem 1), portanto, existe diferença estatística significativa entre as frequências, quando comparado com os demais achados radiográficos $(p=0,0014)$ (ordem 2). 
Tabela 10 - Distribuição numérica $(\mathrm{N})$ de 38 aves com alterações no proventrículo descritas ao laudo radiográfico, analisando a frequência de suspeita clínica de acordo com as espécies - HOVET-FMVZ-USP - 2004-2012

\begin{tabular}{|c|c|c|c|c|c|c|c|c|c|c|}
\hline $\begin{array}{c}\text { SUSPEITA } \\
\text { CLÍNICA }\end{array}$ & 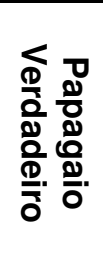 & 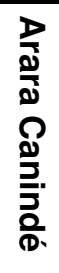 & $\begin{array}{l}\text { ग } \\
\mathbb{\mathbb { D }} \\
\stackrel{\mathbb{D}}{二} \\
\mathbb{D}\end{array}$ & 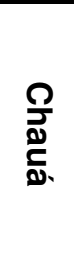 & 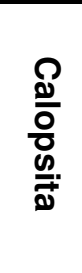 & 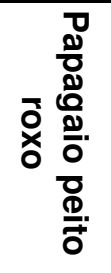 & $\frac{-1}{\bar{z}}$ & 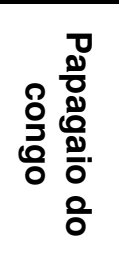 & 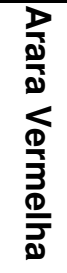 & 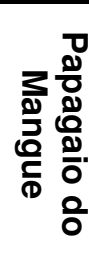 \\
\hline PDD & 2 & 1 & & & 1 & & 1 & & 1 & 1 \\
\hline $\begin{array}{l}\text { Gastroenterite } \\
\text { / Enterite }\end{array}$ & 3 & & & & 2 & & & & 1 & 1 \\
\hline $\begin{array}{c}\text { Corpo } \\
\text { Estranho / } \\
\text { intoxicação }\end{array}$ & 2 & & & & 1 & & & & & \\
\hline Má absorção & & & 1 & & & & & & & \\
\hline Ascite & 1 & & & & & & & & & \\
\hline $\begin{array}{c}\text { Agente } \\
\text { Infeccioso do } \\
\text { TGI }\end{array}$ & 1 & & & & 5 & & & & & 1 \\
\hline $\begin{array}{l}\text { Pneumonia / } \\
\text { Aerosaculite }\end{array}$ & 4 & & & & 1 & & & & & \\
\hline $\begin{array}{l}\text { Incoordenação } \\
\text { / Convulsão }\end{array}$ & 1 & & & 1 & & & & & & \\
\hline $\begin{array}{c}\text { Alteração no } \\
\text { baço }\end{array}$ & 1 & & & & & & & & & \\
\hline $\begin{array}{c}\text { Pancreatite / } \\
\text { insuficiência } \\
\text { pancreática }\end{array}$ & & & 1 & & 1 & & & & & \\
\hline $\begin{array}{l}\text { Deficiência } \\
\text { nutricional }\end{array}$ & 1 & & & & 1 & & & & & \\
\hline $\begin{array}{c}\text { Alterações } \\
\text { ósseas }\end{array}$ & 1 & & & & & & & & & \\
\hline
\end{tabular}

Dentre as espécies os casos de agentes infecciosos na espécie Calopsita apresentaram as maiores frequências $(p<0,0001)$ (ordem 1) existindo assim diferença estatística significativa entre as frequências $(p=0,0008)$, quando comparado com as demais casos e espécies. Seguidos estão os casos de pneumonia/aerosaculite em Papagaio-Verdadeiro $(p<0,0001)$ (ordem 2). 
Tabela 11 - Distribuição numérica $(\mathrm{N})$ de 38 aves com alterações no proventrículo descritas ao laudo radiográfico, analisando a frequência de suspeita clínica de acordo com idades dos animais - HOVET-FMVZ-USP - 2004-2012

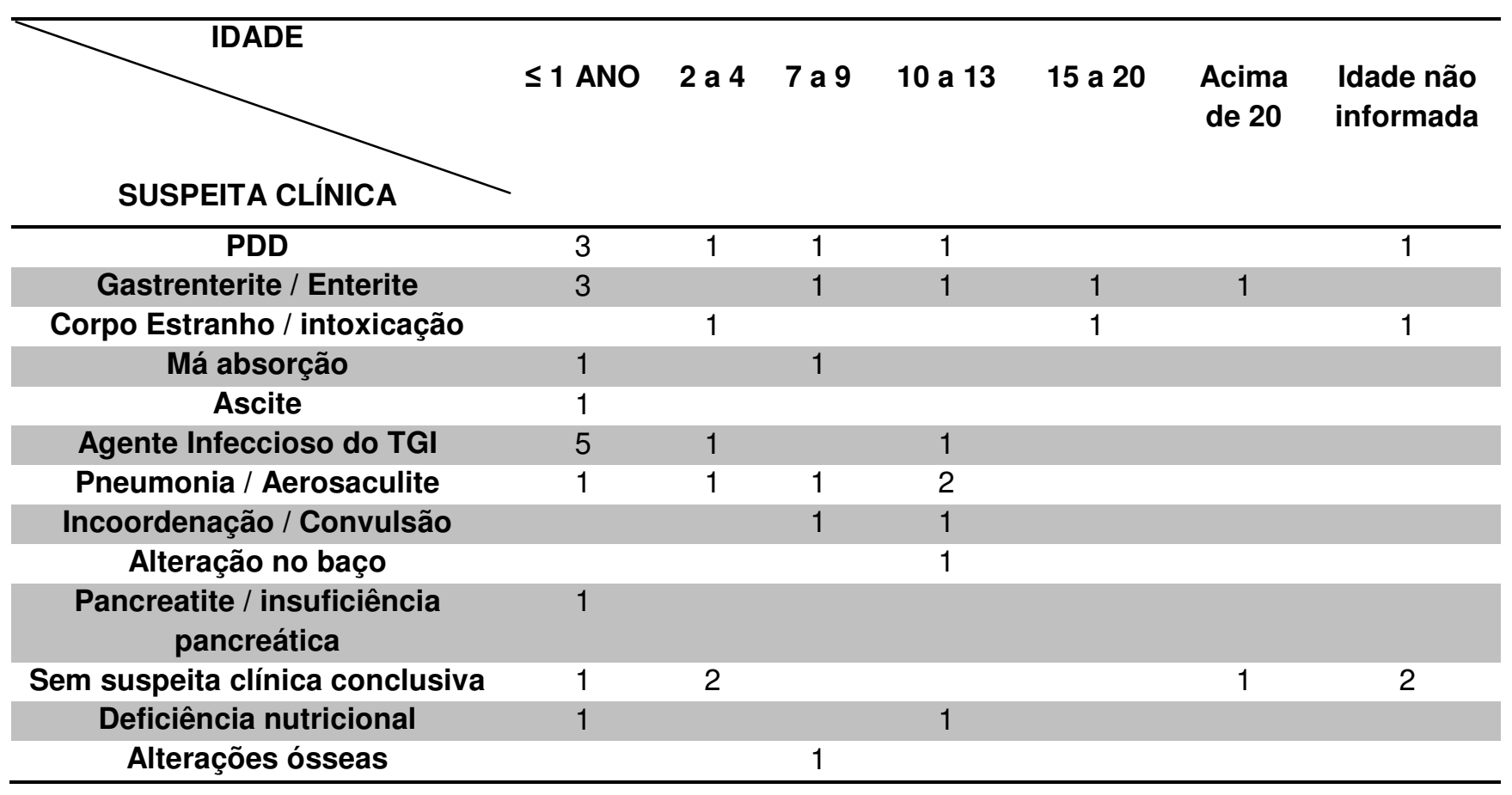

Com relação às idades e afecções, os animais jovens (com 1 ano ou menos) tiveram como suspeita clínica mais frequente as afecções por agente infeccioso do TGI ( $p=0,0164$ ) (ordem 1), portanto, existe diferença estatística significativa entre as frequências $(p<0,0001)$, quando estes são comparados com os demais casos. Seguidos estão os casos de PDD e gastroenterite $(p<0,0001)$ (ordem 2$)$. 
Tabela 12 - Distribuição de 10 aves com exame radiográfico contrastado (dentre as 38 aves estudadas com alteração no proventrículo ao laudo radiográfico) em relação às suspeitas de PDD (clínica e ao laudo radiográfico), de acordo com a espécie, idade e tipo de exame radiográfico - HOVET-FMVZ-USP - 2004-2012

\begin{tabular}{|c|c|c|c|c|c|c|}
\hline CASO & Família & $\begin{array}{c}\text { Nome } \\
\text { Científico }\end{array}$ & Idade & $\begin{array}{l}\text { Suspeita na } \\
\text { avaliação } \\
\text { clínica }\end{array}$ & $\begin{array}{c}\text { Sugerido pelo } \\
\text { laudo } \\
\text { radiográfico }\end{array}$ & $\begin{array}{c}\text { Exame } \\
\text { Contrastado }\end{array}$ \\
\hline 1 & Cacatuidae & $\begin{array}{l}\text { Nymphicus } \\
\text { hollandicus }\end{array}$ & 2 anos & + & & Não \\
\hline 2 & Psittacidae & $\begin{array}{l}\text { Amazona } \\
\text { aestiva }\end{array}$ & Indeterminada & + & & Não \\
\hline 3 & & $\begin{array}{c}\text { Amazona } \\
\text { aestiva }\end{array}$ & 7 anos & + & & Não \\
\hline 4 & & $\begin{array}{c}\text { Ara } \\
\text { chloroptera }\end{array}$ & 4 meses & + & + & Sim \\
\hline 5 & & Ara ararauna & 4 meses & + & & Não \\
\hline 6 & & $\begin{array}{c}\text { Polytelis } \\
\text { anthopeplus }\end{array}$ & 8 anos & & + & Não \\
\hline 7 & & $\begin{array}{c}\text { Amazona } \\
\text { vinacea }\end{array}$ & 4 anos & & + & Não \\
\hline 8 & & $\begin{array}{l}\text { Pyrrhura } \\
\text { frontalis }\end{array}$ & 10 anos & + & & Não \\
\hline 9 & & $\begin{array}{c}\text { Amazona } \\
\text { amazonica }\end{array}$ & 2 meses & + & + & Sim \\
\hline 10 & & $\begin{array}{c}\text { Polytelis } \\
\text { anthopeplus }\end{array}$ & 8 anos & & + & Não \\
\hline $\begin{array}{l}\text { mero de } \\
\text { orrências }\end{array}$ & & & $\begin{array}{c}\text { Média idade } \\
4,43 \text { anos } \\
\end{array}$ & $7(58,3 \%)$ & $5(41,7 \%)$ & \\
\hline
\end{tabular}

Para a tabela acima, calculou-se o coeficiente Kappa, que mede a concordância entre os métodos utilizados.

Quando avaliada a concordância entre os métodos "suspeita clínica sem confirmação pelo exame radiográfico" e o "sugerido ao radiográfico sem suspeita clínica", considerando-se duas categorias (positivo e negativo), foi identificada fraca concordância entre os métodos (Kappa = -0,60; IC95\%: -0,032 e -1,0; p=0,0192).

Quando avaliada a concordância entre os 3 métodos ("suspeita clínica sem confirmação pelo exame radiográfico" e o "sugerido ao radiográfico sem suspeita clínica" e "casos com exame contrastado"), considerando-se duas categorias (positivo e negativo), foi identificada fraca concordância entre os métodos (Kappa = 0,071; IC95\%: -0,429 e 0,286; $p<0,05)$. 
Entretanto, em $20 \%$ dos casos os 3 métodos apresentaram diagnóstico positivo para suspeita de PDD (caso 4: Ara chloroptera e caso 9: Amazona amazonica). Na interpretação dos resultados por análises estatísticas, as avaliações onde o exame contrastado foi utilizado, foram os únicos casos em que houve compatibilidade entre "suspeita clínica" e os casos "sugeridos pelo laudo radiográfico" (2/2, 100\%). Isso pode sugerir que, quando há suspeita clínica de PDD, há maior chance de sucesso diagnóstico quando o exame contrastado é realizado. 
Tabela 13 - Distribuição numérica de 38 aves estudadas com alteração no proventrículo ao laudo radiográfico, analisando a frequência de suspeita clínica de acordo com os achados radiográficos - HOVET-FMVZ-USP - 2004-2012

\begin{tabular}{|c|c|c|c|c|c|c|c|c|c|c|c|}
\hline $\begin{array}{c}\text { Achado } \\
\text { Radiográfico }\end{array}$ & 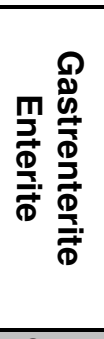 & D̆ & 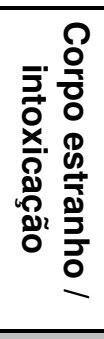 & 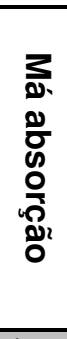 & 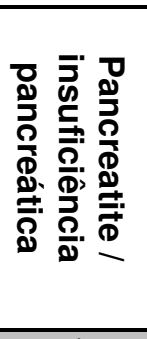 & 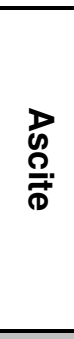 & 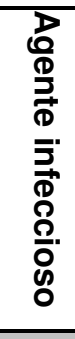 & 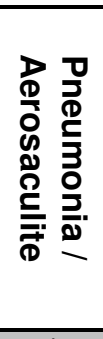 & 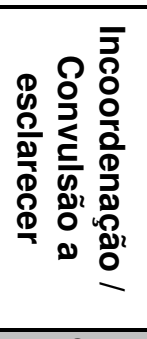 & 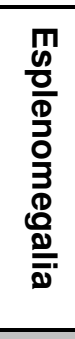 & 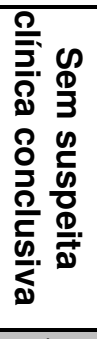 \\
\hline $\begin{array}{l}\text { Dilatação do } \\
\text { proventrículo por } \\
\text { gás e líquido }\end{array}$ & 3 & 4 & 2 & 1 & 1 & & 5 & 1 & 2 & & 1 \\
\hline $\begin{array}{c}\text { Aumento do } \\
\text { proventrículo por } \\
\text { gás }\end{array}$ & 1 & & 1 & & & & & 2 & 1 & 1 & 2 \\
\hline $\begin{array}{l}\text { Dilatação do } \\
\text { proventrículo por } \\
\text { conteúdo líquido }\end{array}$ & 2 & 1 & & & & 1 & & 2 & 3 & & 2 \\
\hline \multicolumn{12}{|l|}{$\begin{array}{l}\text { Dilatação PV visto } \\
\text { ao contraste }\end{array}$} \\
\hline $\begin{array}{l}\text { Falhas de } \\
\text { preenchimento em } \\
\text { PV ao contraste }\end{array}$ & 1 & 2 & 1 & & & & 1 & & & & 1 \\
\hline $\begin{array}{l}\text { Retenção / retardo } \\
\text { contraste PV }\end{array}$ & 1 & & & & & & & & & & \\
\hline $\begin{array}{l}\text { Espessamento de } \\
\text { paredes PV }\end{array}$ & 3 & & 1 & & 1 & & & & 1 & & \\
\hline $\begin{array}{l}\text { Homogeneidade / } \\
\text { distensão } \\
\text { abdominal difusa }\end{array}$ & 3 & 3 & & 1 & & 1 & & 3 & 1 & 1 & 2 \\
\hline $\begin{array}{c}\text { Conteúdo líquido } \\
\text { em alças } \\
\text { intestinais }\end{array}$ & 1 & & & & & & & & & & \\
\hline $\begin{array}{c}\text { Área difusa } \\
\text { homogênea } \\
\text { deslocando alças } \\
\text { intestinais }\end{array}$ & & 1 & & & & & 3 & & 2 & 1 & \\
\hline Dilatação de alças & & 1 & & & & & 1 & 2 & 1 & & \\
\hline $\begin{array}{c}\text { Conteúdo / gás em } \\
\text { inglúvio }\end{array}$ & 3 & 1 & 1 & & & & 3 & & 2 & & 1 \\
\hline $\begin{array}{l}\text { Alteração em } \\
\text { ventrículo }\end{array}$ & 1 & & & & & & & & 1 & & \\
\hline $\begin{array}{l}\text { Transito GI } \\
\text { retardado }\end{array}$ & 3 & 2 & 1 & & & & 1 & 1 & & & 2 \\
\hline
\end{tabular}

Com relação ao achado radiográfico correlacionado com a suspeita clínica, observa-se que existe diferença estatística significativa entre os casos de dilatação do proventrículo por gás e líquido nas suspeitas de agente infeccioso do TGI e os demais achados e suspeitas, pois apresentaram as maiores frequências $(p=0,0214)$ (ordem 1). 
Tabela 14 - Distribuição numérica de 38 aves, analisando a frequência de sintomas de acordo com os achados radiográficos - HOVET-FMVZ-USP - 2004-2012

\begin{tabular}{|c|c|c|c|c|c|c|c|c|c|c|c|c|c|c|c|c|}
\hline Sintomas & 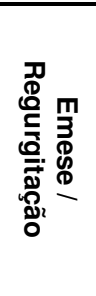 & 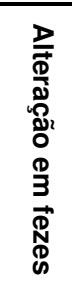 & 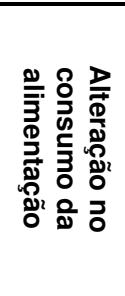 & 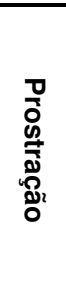 & 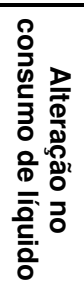 & 疍 & 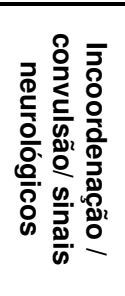 & 을 & 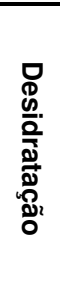 & 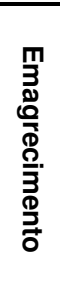 & 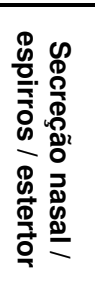 & 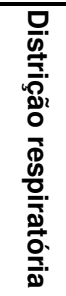 & 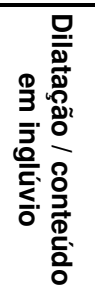 & 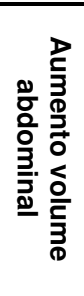 & 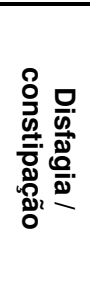 & $\frac{\text { 음 }}{\text { 함 }}$ \\
\hline $\begin{array}{l}\text { Dilatação do } \\
\text { proventrículo } \\
\text { por gás e } \\
\text { líquido }\end{array}$ & 5 & 10 & 8 & 8 & 2 & 1 & 1 & 3 & 2 & 7 & 2 & 1 & 1 & 1 & 2 & 5 \\
\hline $\begin{array}{l}\text { Aumento do } \\
\text { proventrículo } \\
\text { por gás }\end{array}$ & 5 & 4 & 4 & 3 & 3 & 1 & 1 & 1 & & 1 & & 1 & & 1 & & \\
\hline $\begin{array}{l}\text { Dilatação do } \\
\text { proventrículo } \\
\text { por conteúdo } \\
\text { líquido }\end{array}$ & 3 & 4 & 5 & 6 & 2 & 2 & 4 & 1 & 1 & 2 & 3 & 1 & 1 & 1 & & 1 \\
\hline $\begin{array}{c}\text { Dilatação PV } \\
\text { visto ao } \\
\text { contraste }\end{array}$ & 2 & 2 & 2 & 2 & 1 & & & & 1 & 1 & & & 1 & & & \\
\hline $\begin{array}{c}\text { Falhas de } \\
\text { preenchimento } \\
\text { em PV ao } \\
\text { contraste }\end{array}$ & 2 & 3 & 2 & 1 & & & & & & 1 & 1 & & 1 & & & \\
\hline $\begin{array}{c}\text { Retenção } \\
\text { contraste PV }\end{array}$ & 1 & 1 & & & & & & & & & & & & & & \\
\hline $\begin{array}{l}\text { Espessamento } \\
\text { de paredes PV }\end{array}$ & 4 & 4 & 3 & 4 & 1 & 1 & 1 & 1 & 2 & 1 & & & & & & 1 \\
\hline $\begin{array}{l}\text { Homogeneidad } \\
\text { e / distensão } \\
\text { abdominal } \\
\text { difusa }\end{array}$ & 4 & 7 & 7 & 8 & 1 & 2 & 3 & & 1 & 4 & 1 & 1 & 2 & & & 1 \\
\hline $\begin{array}{l}\text { Conteúdo } \\
\text { líquido em } \\
\text { alças intestinal }\end{array}$ & 1 & & 1 & 1 & 1 & & 1 & 1 & & 1 & & & 1 & & & \\
\hline $\begin{array}{c}\text { Área difusa } \\
\text { homogênea } \\
\text { deslocando } \\
\text { alças } \\
\text { intestinais }\end{array}$ & 1 & 3 & 2 & 3 & 2 & & 1 & 1 & 1 & & 1 & 1 & 1 & 2 & 1 & 3 \\
\hline $\begin{array}{l}\text { Dilatação de } \\
\text { alças }\end{array}$ & 4 & 4 & 5 & 5 & 2 & 2 & 1 & 1 & & 1 & & & 1 & 1 & & \\
\hline $\begin{array}{l}\text { Conteúdo / gás } \\
\text { em inglúvio }\end{array}$ & 4 & 6 & 4 & 6 & & & 1 & 2 & & 3 & 1 & & 1 & & 2 & 1 \\
\hline $\begin{array}{l}\text { Alteração em } \\
\text { ventrículo }\end{array}$ & 2 & 6 & 5 & 5 & & 1 & 1 & 2 & 1 & 3 & & 2 & & & 1 & 3 \\
\hline $\begin{array}{l}\text { Retardo no } \\
\text { transito GI }\end{array}$ & 3 & 4 & 3 & 2 & 2 & 1 & & & 1 & 2 & 1 & & & & & \\
\hline
\end{tabular}

Com relação ao achado radiográfico correlacionada com a suspeita clínica, observa-se que existe diferença estatística significativa entre as frequências $(p<0,0001)$, visto que os casos de "dilatação do proventrículo por gás e líquido" 
foram mais frequentemente encontrados quando há sintomas de alteração nas fezes, apresentando as maiores frequências $(p=0,0351)$ (ordem 1); seguidas de alteração no consumo de alimento e prostração/ apatia $(p=0,0119)$ (ordem 2). A prostração /apatia também teve frequência de ordem 2 nos casos quando encontrado "homogeneidade / distensão abdominal difusa".

Já na ordem 3 estão as frequências encontradas nos achados de "homogeneidade / distensão abdominal difusa" foram visto nos casos onde apresentavam prostração e alteração no consumo da alimentação e a "dilatação do proventrículo por gás e líquido" nos casos onde havia emagrecimento $(p=0,0051)$.

\subsection{ILUSTRAÇÕES}

As figuras de 1 a 4 ilustram alguns dos achados observados nos exames radiográficos. Os anexos A, figura 5 e B, figura 6 ilustram de forma esquemática a anatomia do sistema digestório das aves. 
Figura 1 - Exame radiográfico simples em projeção laterolateral $(A)$ e ventrodorsal $(B)$ de papagaio-verdadeiro adulto. Presença de acentuada dilatação de proventrículo por conteúdo gasoso e alimentar (heterogêneo) medindo $5.0 \mathrm{~cm}$ (eixo craniocaudal) x 3.0 $\mathrm{cm}$ (eixo ventrodorsal)
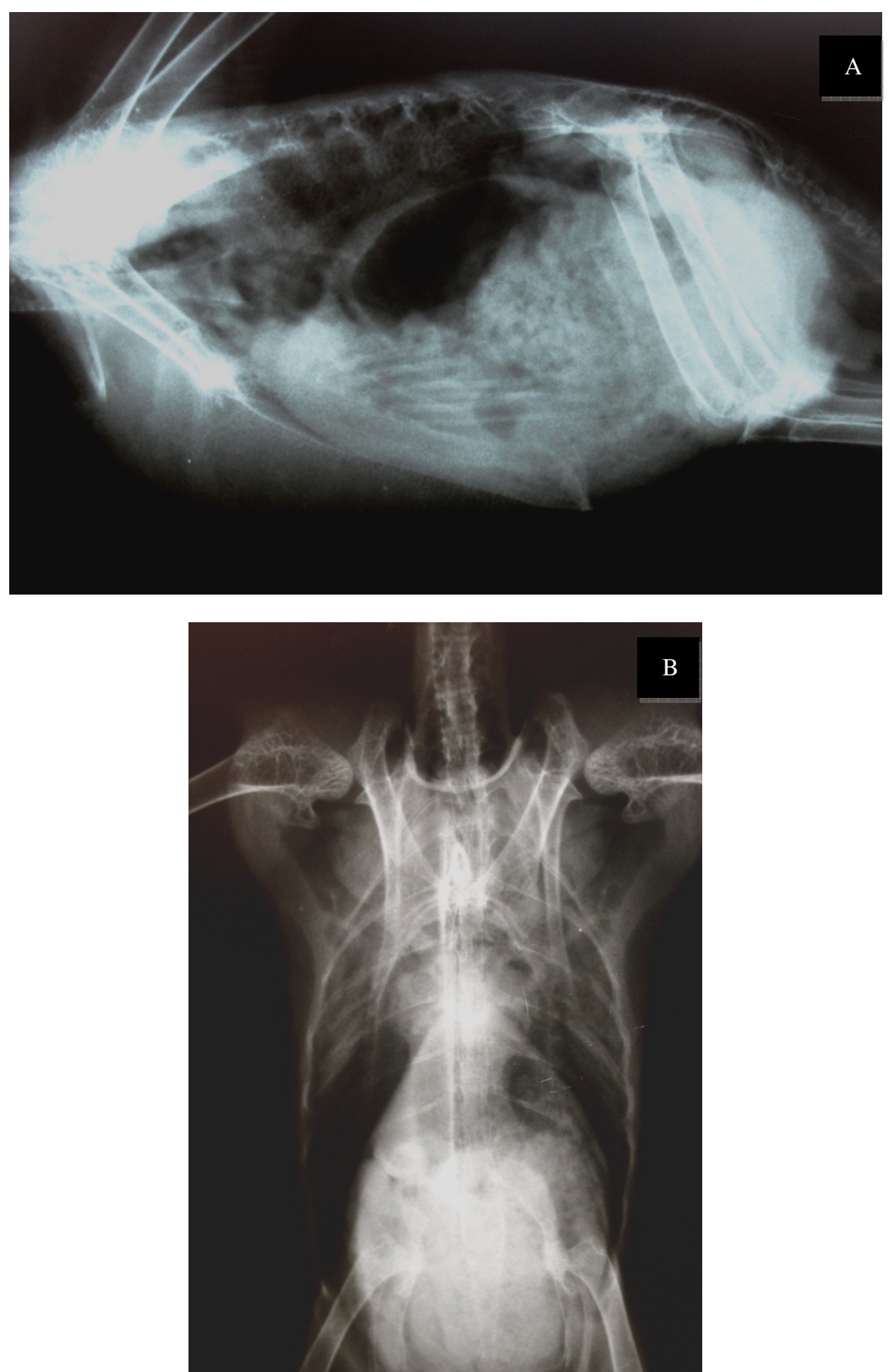

Fonte: Arquivo do serviço de diagnóstico por imagem VCI - FMVZ-USP (2013) 
Figura 2 - Exame radiográfico contrastado em projeção laterolateral $(A)$ e ventrodorsal $(B)$ com administração de contraste de bário no caso clínico da figura 1. O animal apresentou evolução lenta da progressão do contraste do inglúvio para proventrículo, e ainda com dilatação de proventrículo e falha de preenchimento por conteúdo alimentar
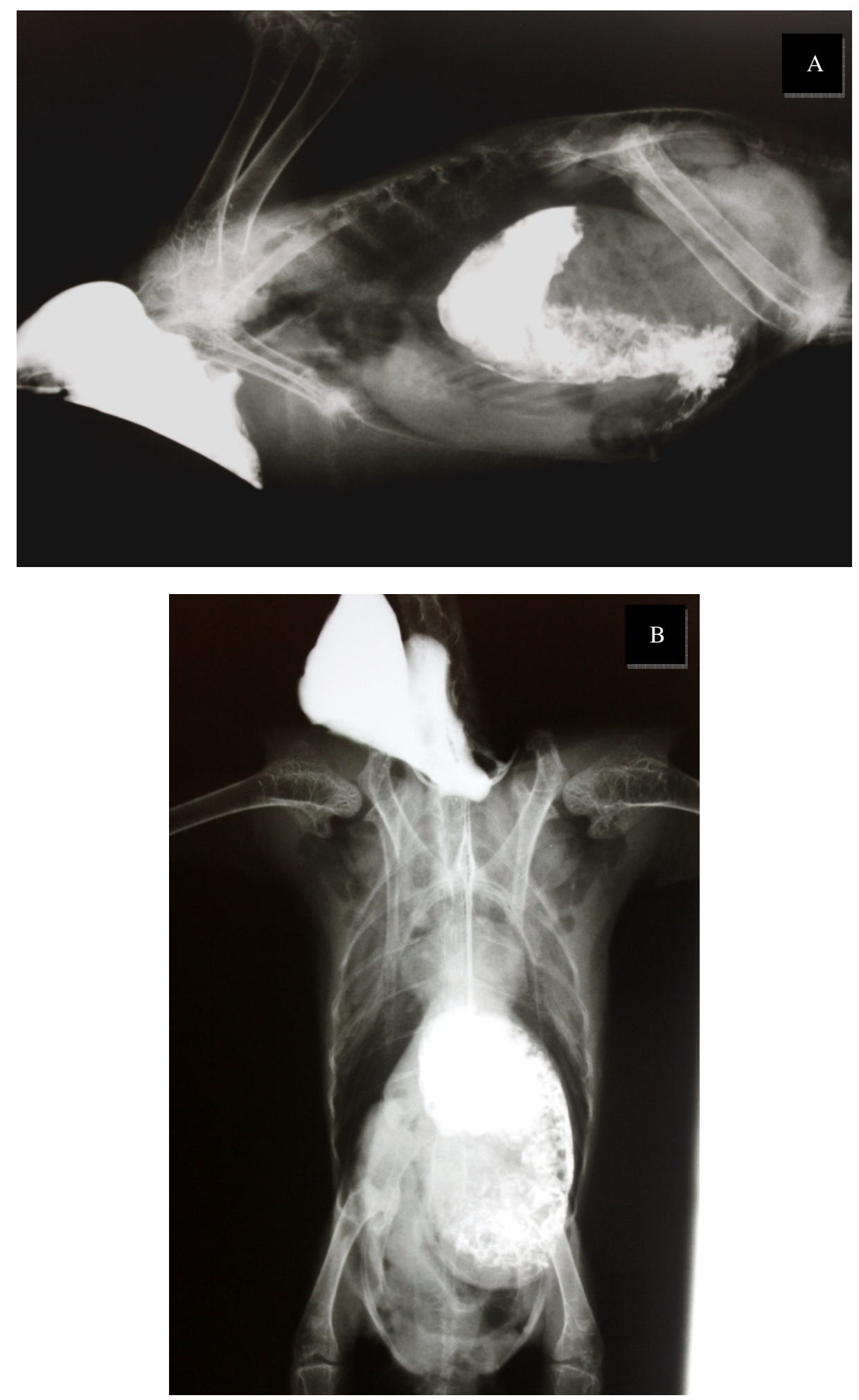

Fonte: Arquivo do serviço de diagnóstico por imagem VCI - FMVZ-USP (2013). 
Figura 3 - Exame radiográfico simples em projeção laterolateral de papagaio-verdadeiro adulto. Presença de acentuada dilatação de proventrículo por conteúdo gasoso e heterogêneo

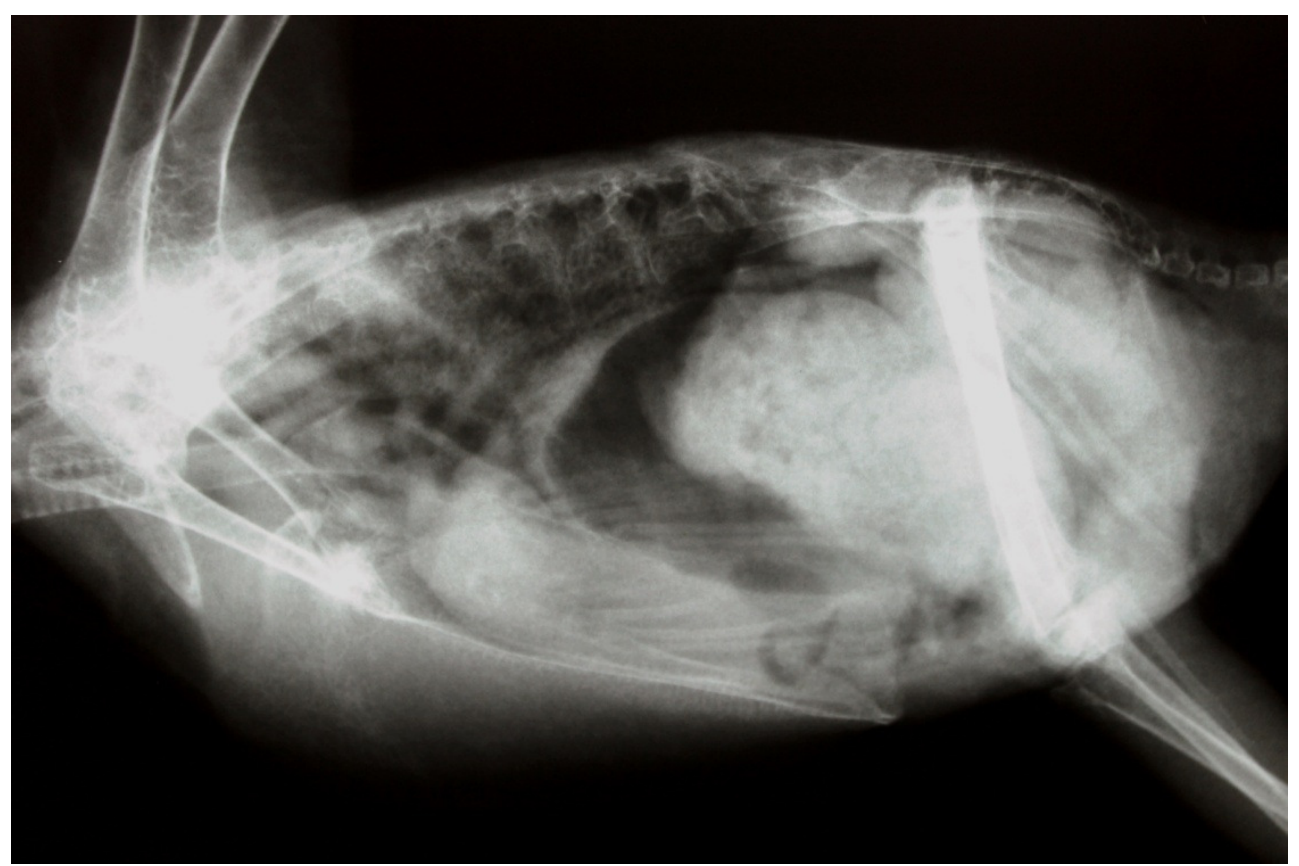

Fonte: Arquivo do serviço de diagnóstico por imagem VCI - FMVZ-USP (2013

Figura 4 - Exame radiográfico simples em projeção laterolateral de papagaio-verdadeiro adulto. Presença de dilatação de proventrículo por conteúdo radiodensidade gás e líquido medindo até $3,0 \mathrm{~cm}$ no eixo ventrodorsal e conteúdo de radiodensidade líquido em inglúvio

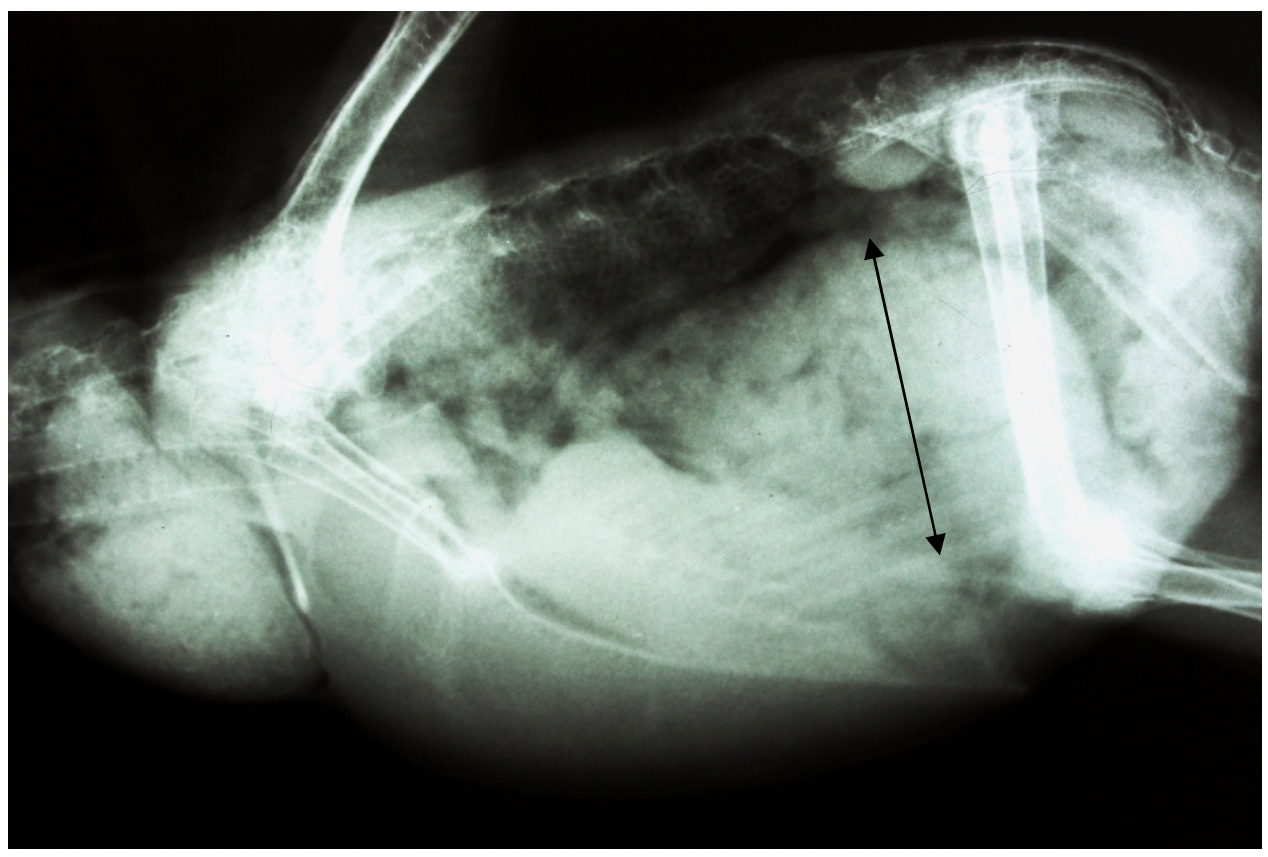

Fonte: Arquivo do serviço de diagnóstico por imagem VCI - FMVZ-USP (2013) 


\section{DISCUSSÃO}

São de grande importância as diferenças anatômicas do sistema gastrointestinal entre os psitacídeos e os mamíferos, os quais são usualmente mais estudados e conhecidos. Deste modo, considera-se indispensável para o reconhecimento e a interpretação das alterações radiográficas, literatura que abranja as características anatômicas e as alterações do sistema gastrointestinal das aves (SMITH; SMITH, 1997; O'MALLEY, 2005). Neste trabalho abordamos apenas as alterações radiográficas do sistema digestório, mais especificamente do proventrículo dos psitacídeos.

O correto posicionamento radiográfico e a escolha adequada dos fatores de exposição se fazem imprescindíveis para a produção de radiografias diagnósticas de alta qualidade (RUPLEY, 1999). No trabalho em tela, os equipamentos radiográficos e a técnica empregada produziram imagens que permitiram analisar satisfatoriamente a cavidade celomática.

No período de 2004 a 2012, foram estudados exames radiográficos de 38 aves, portadoras de alguma alteração no proventrículo citadas aos laudos radiográficos. As aves registradas neste estudo pertenceram unicamente a ordem dos Psittaciformes dentre eles somente duas famílias foram classificadas, a Pcittacidae e a Cacatuidae (71,05\% e $28,95 \%$, respectivamente). De acordo com a literatura, estas são as aves mais populares, mantidas como animais de estimação (PETRAK; GILMORE, 1969; WALLACH; BOEVER, 1983; FORBES; LAWTON, 1996). O papagaio-verdadeiro (Amazona aestiva) constituiu um contingente bastante abundante, sendo a espécie mais comum (17/38, 44,8\%). Os psitacídeos tem grande capacidade de interação, o que thes conferem posição entre os companheiros preferidos do homem (FORBES; LAWTON, 1996).

A variável sexo não foi considerada nesse estudo devido a escassez de características sexuais externas em muitas espécies de aves Psittaciformes, e técnicas para a determinação do sexo são exigidas para tal (HALVERSON, 1997). 
A análise dos resultados alcançados foi abordada avaliando as espécies mais frequentemente atendidas, as idades dos animais em questão, os exames completares mais solicitados, os achados radiográficos descritos nos laudos radiográficos, os sintomas descritos nos prontuários de atendimento e as suspeitas diagnósticas (tanto clínica e quanto citada ao laudo radiográfico), para facilitar a exposição dos mesmos.

Através da análise estatística observou-se que entre os 38 casos analisados, os sintomas mais frequentes foram apatia/prostração $(20 / 38,52,63 \%)$ e as alterações no apetite como a anorexia/hiporexia também (20/38, 52,63\%), seguido da emese/regurgitação (15/38 39,47\%). Os resultados apresentados estão de acordo com o autor Morrisey (1999), que relata esses como os sintomas mais encontrados nas aves com alteração em proventrículo. Já entre os exames contrastados as alterações nas fezes $(7 / 10,70 \%)$ foi o sintoma mais comum, seguido emese/regurgitação e apatia/prostração (6/10, 60\%).

Dentre as suspeitas clínicas mais frequentemente interrogadas, a PDD foi a mais citada (10/38, 26,32\%), seguida da suspeita envolvendo algum tipo de Agente infeccioso do TGI $(7 / 38,18,42 \%)$ e de animais sem suspeita clínica conclusiva (7/38, $18,42 \%$ ). Isso coincide com o citado à bibliografia (INGRAM, 1990) que indica que a PDD ainda é uma das injúrias mais preocupantes e tem caráter prioritário quando encontrados achados radiográficos e sintomas que levam a tal suspeita, tendo em vista que pode ser fatal. A falta de suspeita conclusiva ser uma das características mais frequentes dentre os casos, pode demonstrar que muitas vezes algumas doenças possuem sintomas similares ou até mesmo ausência de sintomas que incitariam mais facilmente a suspeita diagnóstica, fato também descrito por alguns autores (MORRISEY, 1999; SCHMIDT, 1999).

Analisando as suspeitas clínicas em cada espécie dentre os casos em estudo, a calopsita (Nymphicus hollandicus) teve dentre as suspeitas diagnósticas mais frequentes as infecções do trato gastrointestinal (5/38, 13,16\%), coincidindo com citado pelos autores Gancz et al. (2009), seguida da aerosaculite/pneumonia (4/38, $10,53 \%$ ) e da Gastroenterite nos papagaios verdadeiros (Amazona aestiva) (3/38, 7,89\%) citada como injúrias comuns por Levine (2003). O autor Marietto-Gonçalves 
(2009) ressalta que os sintomas em trato respiratório podem ser secundários à PDD, pois pode induzir pneumonia aspirativa. Porém, ainda podemos considerar que a suspeita clínica de alteração no sistema respiratório poderia ser justificada devido ao fato da distrição respiratória ser um achado considerável em alguns casos de dilatação do proventrículo, por restrição volumétrica e compressão de sacos aéreos.

Quanto à análise das idades dos animais relacionada com a suspeita diagnóstica, o agente infeccioso do TGI nos animais jovens (com 1 ano ou menos) foi a mais frequente $(5 / 38,13,16 \%)$, A PDD e Gastroenterite foram secundariamente as suspeitas mais citadas nos animais de mesma faixa etária $(3 / 38,7,89 \%)$, coincidindo com o descrito em literatura (CHEVILLE, 1978; WORELL, 2000; LEVINE, 2003).

$\mathrm{Na}$ avaliação final da conclusão dos casos, grande parte dos animais (22/38, $57,89 \%)$ não retornou ao atendimento no ambulatório de aves do HOVET - FMVZ USP. Dos casos que retornaram, nove $(9 / 38,23,68 \%)$ obtiveram melhora clínica e sete deles $(7 / 38,18,42 \%)$ tiveram alguma piora ou chegaram a óbito. A falta de retornos e conclusão ao histórico clínico dificulta um estudo detalhado dos possíveis diagnósticos, evoluções clínicas e avaliação dos procedimentos tomados.

O achado radiográfico mais frequente foi a "Dilatação do proventrículo por de radiodensidade gás e líquido" (13/38, 34,21\%), seguidas por "Dilatação do proventrículo por conteúdo de radiodensidade líquido" (10/38, 26,32\%) e Homogeneidade em topografia de alças intestinais" (10/38, 26,32\%). Na "dilatação do proventrículo por gás e líquido", observou-se que na maior parte das vezes esta foi encontrada quando a suspeita clínica estava relacionada com agente infeccioso do TGI $(5 / 38,13,16 \%)$, seguida da PDD (4/38, 10,53\%). O trabalho de Dennison et al. (2009) cita que pode haver grande variação de densidades em proventrículo quando este está dilatado e que a visibilização de gás no mesmo por ser decorrente a jejum prolongado ou secundário a procedimento anestésico. Outra literatura cita que várias doenças podem ter como achado radiográfico a presença de gás em proventrículo e alças, incluindo enterite, impactação, neoplasia, ingestão de corpo estranho, parasitismo, intussuscepção, toxicoses e, finalmente, doenças infecciosas como a PDD (MCMILLAN, 1994,1999). 
$\mathrm{Na}$ análise dos achados radiográficos correlacionada com os sintomas mais frequentes, encontrou-se a "dilatação do proventrículo por gás e líquido" com maior frequência nos casos onde haviam sintomas de alterações nas fezes (10/38, $26,38 \%$ ), seguida da prostração/apatia, alteração no consumo do alimento (8/38, $21,05 \%$ cada) e emagrecimento (7/38, 18,42\%). Esses achados são condizentes com os que citam vários autores, descrevendo sintomas semelhantes quando há dilatação de proventrículo, podendo compreender grande variedade de doenças, dificultando diferenciação entre si (INGRAM, 1990; LUMEIJ, 1999; GREGORY, 1995; HOEFER, 1997; MORRISEY, 1999; LANGLOIS, 2003). De acordo com Morrisey (1999) os sinais clínicos podem variar de acordo com o agente causador, mas geralmente incluem a regurgitação, perda de peso, anorexia ou uma mudança de apetite (aumentada ou diminuída).

A "homogeneidade / distensão abdominal difusa" foi a segunda alteração mais frequente, porém mais encontrada nos casos que apresentavam prostração/apatia $(8 / 38,21,05 \%)$, seguida das alterações nas fezes e alteração no consumo do alimento $(7 / 38,18,42 \%$ cada uma). A literatura que cita tal achado radiográfico para efeito comparativo parece ser escassa, pois não foi encontrada.

O presente trabalho também analisou quantas vezes realizou-se a Medição do PV ao laudo radiográfico, no qual também foi dado descrito na maior parte dos casos (14/38, 36,84\%). Este dado poderia ser melhor utilizado na rotina com auxílio da técnica descrita no trabalho de Dennison et al. (2009), onde a medição do órgão, comparada ao tamanho da quilha do animal, permitiu de forma consistente a identificação do dilatação proventricular associada à doenças. $O$ mesmo estudo ressalta que o proventrículo não pode ser medido com precisão em todos os animais, devido a fallta de delimitação da margem ventral proventricular que pode ocorrer em aves com hepatomegalia, ascite ou quando a dilatação ocorre sem a presença de gás intraluminal. Cita ainda que, com o aumento da disponibilidade de radiografias digitais, os casos em que a medida pode ser feita aumentará, devido ao melhora na qualidade das imagens, delimitações de estruturas e facilidade de ajustes de contrastes. 
Dos exames complementares mais frequentemente solicitados, além do exame radiográfico simples comum a todos os casos, o exame radiográfico contrastado teve maior índice (10/38, 26,32\%), seguido do hemograma e gram de fezes $(8 / 38,21,05 \%$ cada um). Dentre os exames contrastados na maior parte das vezes a suspeita envolvia o TGI (4/10,40\%). Dentre elas estão englobadas a casos de gastrenterite / enterite, corpo estranho, intoxicação e os agentes infeccioso do TGI. Com relação a suspeita de PDD, esta só foi uma das suspeitas diagnósticas em 2 casos dos exames contrastados $(2 / 10,20 \%)$. A literatura cita que o exame contrastado é o exame de primeira escolha quando se inicia investigação de alterações no trato gastrointestinal e é de grande utilidade para descartar causas obstrutivas (PINTO, 2007).

No presente estudo dos 10 casos suspeitos de PDD, sete casos (7/10, 70\%) tiveram suspeita na avaliação clínica e cinco $(5 / 10,50 \%)$ no exame radiográfico, e dentre esses, somente em dois casos $(2 / 10,20 \%)$ foi duplamente sugerido como suspeita na avaliação clínica e no exame radiográfico. Dos 7 casos em que havia suspeita clínica, mesmo com $\mathrm{N}$ pequeno (2/10, 20\%), observou-se que os únicos casos confirmados radiograficamente foram os que houveram solicitação do exame contrastado (Tabela 12). Em outros três casos (3/10,0 30\%) o exame radiográfico colocou a PDD como suspeita diagnóstica sem que esta tivesse sido anteriormente descrita na suspeita clínica. Nos demais cinco casos em que houve suspeita clínica $(5 / 10,50 \%)$ não foi possível confirmar o diagnóstico através de exame radiográfico simples. O que estimula a pensarmos que o exame contrastado é um dos métodos mais precisos na suspeita de PDD, indicando que há grande chance de sucesso quando o exame contrastado for bem indicado. Estes dados auxiliariam o incentivo no aumento na solicitação deste tipo de exame, visto que dos 38 casos analisados, somente $26,32 \%$ foram encaminhados para avaliação por exame contrastado, o que pode se considerar este um percentual baixo. Não foi possível concluir as causas desse percentual baixo.

Devemos lembrar que a literatura descreve que muitas vezes pode-se suspeitar clinicamente de PDD e esta não ser confirmada pelo exame radiográfico, assim como pode-se não suspeitar de tal patologia e este ser umas das hipóteses diagnósticas no exame radiográfico, principalmente quando lembramos que a PDD 
pode ocorrer de forma silenciosa, assintomática ou sem alterações anatômicas evidentes (SCHMIDT, 1999).

Nos mesmos casos onde optou-se pela análise através do exame contrastado, observou-se que os achados radiográficos mais frequentes foram a "retenção do meio de contraste ou evolução lenta" e "espessamento de parede em PV ou ventrículo" (5/10, 50\% cada um) seguido da "dilatação do proventrículo" (4/10, $40 \%$ ). Esses achados são os mais relatados na literatura. Podem estar relacionados com PDD e outras doenças que causam lesão e dilatação do mesmo, à exemplo o espessamento de parede que é citado na literatura como um sintoma de infecção micótica e parasitária (SCHMIDT, 1999).

Sendo assim, concordamos, por confirmação dos dados, a hipótese de Schmidt; Reavill e Phalen (2003) onde cita que a dilatação de proventrículo em si não é patognomônica para PDD. Qualquer doença que cause obstrução parcial ou completa dos intestinos resultará em dilação de proventricular. À exemplo estão: a obstrução do intestino delgado, o ílio paralítico (DUSTAN, 1984; GELIS, 2006), o Poxvirus e a Doença da Pacheco (WYSS et al, 2009). Estas afecções também causam a dilatação órgão e podem resultar em lesões histologicamente semelhantes à PDD. Salienta-se que a PDD não atinge necessarimanete o $\mathrm{PV}$, e que outros compartimentos gastrintestinais também podem estar distendidos, porém nenhum destes achados são específicos para PDD (HOEFER, 1997; RITCHIE et al., 2004). 


\section{CONCLUSÕES}

Baseada na metodologia empregada e nos resultados obtidos, foi possível concluir que:

1. O exame radiográfico é importante aliado no diagnóstico das afecções do PV, mais bem visualizado quando este encontra-se com algum conteúdo gasoso. A medição do órgão pode ser um grande aliado e deve ser instituida sempre que possível.

2. O achado radiográfico mais comum do proventrículo propriamente dito, ao exame simples, é a dilatação do PV com diferentes tipos de conteúdo, principalmente nos casos de suspeita de PDD.

3. Os achados mais comuns ao exame contrastado foram a "retenção do meio de contraste ou evolução lenta" e "espessamento de parede em PV ou ventrículo", que são achados importantes e de grande contribuição para o diagnóstico das afecções que envolvem o proventrículo e o TGl.

4. As suspeitas de doenças infecciosas do TGI são comuns, e são citadas com maior frequência em animais com um ano ou menos, enquanto que nas suspeitas de PDD, a idade média é de adultos jovens (4,43 anos).

5. Os sinais clínicos das injúrias que afetam o PV são de carater semelhantes aos que atingem outros órgãos do TGI.

6. A PDD é a doença de maior importância dentre as que atingem o TGI, e deve sempre estar entre o diagnóstico diferencial devido ao seu alto grau de mortalidade.

7. São necessárias medidas que incentivem o retorno dos animais antendidos com melhora ou piora do quadro, para futuros estudos sejam facilitados quanto a evolução clínica.

8. O estudo da ocorrência por meio de arquivos radiográficos talvez subestime a real ocorrência das afecções em proventrículo em psitacídeos. É possível que 
outros casos tenham ocorrido no período consultado, e que não foram diagnosticados por não terem sido realizados os exames radiográficos. 


\section{REFERÊNCIAS}

BENNETT A, R.; DEEM, S. L. O sistema gastrointestinal das aves: I. Compêndio de Educação Continuada para o Médico Veterinário, Florida, v. 1, n. 1, p. 50-56, 1996.

BENEZ, S. M. Aves. 4. ed. Ribeirão Preto: Tecmedd, 2004. p. 21-24.

BERHANE, Y.; SMITH, D. A.; NEWMAN, S.; TAYLOR, M.; NAGY, E.; BINNINGTON, B.; HUNTER, B. Peripheral neuritis in psittacine birds with proventricular dilatationdisease. Avian Pathol., v. 30, p. 563-570, 2001.

BOCHMANN, M.; LUDEWIG, E.; KRAUTWALD-JUNGHANNS, M.; PEES, M. Comparison of the image quality of a high-resolution screen-film system and a digital flat panel detector system in avian radiography. Veterinary Radiology \& Ultrasound, v. 52, n. 3, 2011, p. 256-261.

BOUTETTE, J. B.; TAYLOR, M. Proventricular dilatation disease: a review of research, literature, species differences, diagnostics, prognosis and treatment. Proc Annu Conf Assoc Avian Vet., p. 175-181, 2004.

CARPENTER, J. W.; MASHIMA, T. Y.; RUPPIER, D. J. Exotic animal formulary. 3. ed. Philadelphia: Elsevier Saunders, 2005. p. 564.

CHEVILLE, N. F.; ARP, L. H. Comparative pathologic findings of Escherichia coli infection in birds. Journ of the Amer Veterin Medic Assoc, v. 173, p. 84-587, 1978.

CBRO. COMITÊ BRASILEIRO DE REGISTROS ORNITOLÓGICOS. Lista de aves do Brasil. Versão 25/01/2011. Disponível em: <http://www.cbro.org.br/CBRO/listabr.htm>. Acesso em: 10 jul. 2012.

CRACKNELL, J. Avian radiography and radiology in practice. Veterin Times, v. 34, n. 4, p. 6-7, 2004.

CUBITT, B.; LY, C.; DE LA TORRE, J. C. Identification and characterization of a new intron in Borna disease virus. J Gen Virol., v. 82, n. 3, p. 641, 2001.

DE LA TORRE, J. C. Reverse-genetic approaches to the study of Borna disease virus. Nat Rev Microbiol., v. 4, n. 10, p. 777-783, 2006.

DE KLOET, S. R.; DORRESTEIN, G. M. Presence of avian bornavirus RNA and antiavian bornavirus antibodies in apparently healthy macaws. Avian Dis., v. 53, p. 568573, 2009.

DENNISON, S. E.; ADAMS, W. M.; JOHNSON, P. J.; YANDELL, B. S.; PAULMURPHY, J. R. Prognostic accuracy of the proventriculus: keel ratio for short-term 
survival in psittacines with proventricular disease. Vet Radiol Ultrasound., v. 50, p. 483-486, 2009.

DUKE, G. E. Digestão nas aves. In: DUKES, H. H. Dukes/fisiologia dos animais domésticos. 11. ed. Rio de Janeiro: Guanabara Koogan, 1996. p. 390-397.

DUSTAN, C. F. Proventricular dilatation syndrome in large psittacine parrots. Avian Dis., v. 28, p. 813-815, 1984.

DYCE, K. M.; SACK, W. O.; WENSING, C. J. G. Tratado de anatomia veterinária. 2. ed. Rio de Janeiro: Guanabara Koogan, 1997. p. 631-650.

FORBES, N. A.; LAWTON, M. P. C. Introduction. In: BEYNON, P. H.; FORBES, N. A.; LAWTON, M. P. C. (Ed.). Manual of psittacine birds. Cheltenham: BSAVA, 1996. p. 7-10.

GANCZ, A. Y.; KISTLER, A. L.; GRENINGER, A. L.; FARNOUSHI, Y.; MECHANI, S.; PERL, S.; BERKOWITZ, A.; PEREZ, N.; CLUBB, S.; DERISI, J. L.; GANEM, D.; LUBLIN, A. Experimental induction of proventricular dilatation disease in cockatiels (Nymphicus hollandicus) inoculated with brain homogenates containing avian bornavirus. Virol J., v. 6, p. 100, 2009.

GANCZ, A. Y.; CLUBB, S.; SHIVAPRASAD, H. L. Advanced diagnostic approaches and current management of proventricular dilatation disease. Vet Clin Exot Anim., v. 13, p. 471-494, 2010.

GELIS, S. Evaluating and treating the gastrointestinal system. In: HARRISON, G. J.; LIGHTFOOT, T. L. (Ed.). Clinic avian medicine. Florida: Spix Publishing Inc., 2006. p. $429-432$.

GREGORY, C. R. Proventricular dilatation disease. In: RITCHIE, B. W. (Ed.). Avian viruses: function and control. Lake Worth: Wingers Publishing, 1995. p. 439-448.

GREGORY, C. R.; LATIMER, K. S.; CAMPAGNOLI, R. P.; RITCHIE, B. W. Histologic evaluation of the crop for diagnosis of proventricular dilatation syndrome in psittacine birds. J Vet Diagn Invest., v. 8, p. 76-80, 1996.

GREGORY, C. R.; RITCHIE, B. W.; LATIMER, K. S.; STEFFENS, W. L.;

CAMPAGNOLI, R. P.; PESTI, D.; LUKERT, P. D. Proventricular dilatation disease: a viral epornitic. Proc Annu Conf Assoc Avian Vet., p. 43-52, 1997.

GREGORY, C. R.; RITCHIE, B. W.; LATIMER, K. S.; STEFFENS, W. S.; PESTI, D.; CAMPAGNOLI, R. P.; LUKERT, P. D. Progress in understanding proventricular dilatation disease. Proc Int Avicult Soc., v. 4-8, p.1-6, 1998.

HALVERSON, J. Nonsurgical methods of avian sex identification. In: ALTMAN, R. B.; CLUBB, S. L.; DORRESTEIN, G. M.; QUESENBERRY, K. Avian medicine and surgery. Philadelphia: W. B. Saunders Company, 1997. p. 117-121. 
HARTUNG, K.; LUDEWIG, E.; TELLHELM, B. Röntgenuntersuchung in der Tierarztpraxis. Stuttgart, Germany: Enke Verlag, 2010.

HOEFER, H. L. Diseases of the gastrointestinal tract. In: ALTMAN, R. B.; CLUBB, S. L.; DORRESTEIN, G. M.; QUESENBERRY, K. (Ed.). Avian medicine and surgery. Philadelphia: WB Saunders, 1997. p. 419-53.

HONKAVUORI, K. S.; SHIVAPRASAD, H. L.; WILLIAMS, B. L.; QUAN, P. L.; HORNIG, M.; STREET, C.; PALACIOS, G.; HUTCHISON, S. K.; FRANCA, M.; EGHOLM, M.; BRIESE, T.; LIPKIN, W. I. Novel borna virus in psittacine birds with proventricular dilatation disease. Emerg Infect Dis., v. 14, p. 1883-1886, 2008.

INGRAM, I. A. Proventricular foreign body mimicking proventricular dilation in an umbrella cockatoo. In: ANNUAL CONFERENCE OF THE ASSOCIATION OF AVIAN VETERINARIANS, 1990, Phoenix: Arizona, 1990, p. 314-315.

ISENBÜGEL, E.; WOLVEKAMP, P.; RÜBEL, G. A. (Ed.). Atlas of diagnostic radiology of exotic pets: small mammals, birds, reptiles and amphibians. Philadelphia, PA: W.B. Saunders Company, 1991.

KISTLER, A.; GANCZ, A.; CLUBB, S.; SKEWES-COX, P.; FISCHER, K.; SORBER, K.; CHIU, C. Y.; LUBLIN, A.; MECHANI, S.; FARNOUSHI, Y.; GRENINGER, A.; WEN, C. C.; KARLENE, S. B.; GANEM, D.; DERISI, J. L. Recovery of divergent avian bornaviruses from cases of proventricular dilatation disease: identification of a candidate etiologic agent. Virol J., v. 5, p. 88, 2008.

KOHNO, T.; GOTO, T.; TAKASAKI, T.; MORITA, C.; NAKAYA, T.; IKUTA, K.; KURANE, I. ; SANO, K.; NAKAI, M. Fine structure and morphogenesis of Borna disease virus. J Virol, v. 73, n. 1, p. 760-766, 1999.

KRAUTWALD, M. E.; TELLHELM, B.; HUMMEL, G.; KOSTKA, V. M.; KALETA, E. F. Atlas of radiographic anatomy and diagnosis of cage birds. Hamburg, Germany: Verlag Paul Parey, 1992. p. 31-35.

KRAUTWALD-JUNGHANNS, M. Avian radiology. In: ROSSKOPF JÚNIOR, W. J.; WOERPEL, R. W. Diseases of cage and aviary birds. 3. ed. Baltimore: Williams \& Wilkins, 1996. p. 630-663.

LANGLOIS, I. The anatomy, physiology, and diseases of the avian proventriculus and ventriculus. Veterinary Clin North Am Exot Anim Pract., v. 6, n. 1, p. 85-111, 2003.

LAVIN, L. M. Radiography in veterinary technology. Philadelphia: W. B. Saunders Company, 1994. p. 279-296.

LEVINE, B. S. Common disorders of amazons, australian parakeets, and african grey parrots. Sem in Avian and Exot Pet Med., v. 12, n. 3, p. 125-130, 2003. 
LUBLIN, A.; MECHANI, S.; FARNOUSHI, I.; PERL, S.; BENDHEIM, U. An outbreak of proventricular dilation disease in psittacine breeding farm in Israel. Isr $\mathbf{J}$ Vet Med., v. 61 , n. 1, p. 16-19, 2006.

LUMEIJ, J. T. Gastroenterology. In: RITCHIE, B. W.; HARRISON, G. J.; HARRISON, L. R. (Ed.). Avian medicine: principles and application. Delray Beach (FL): HBD International. Inc, 1999. p. 482-521.

LYMAN, R. Neurologic disorders. In: HARRISON, G. J.; HARRISON, L. R.

Clinical avian medicine and surgery. Philadelphia: PA: WB Saunders, 1986. p. 486-490.

MARIETTO-GONÇALVES, G. A.; TRONCARELLI, M. Z.; SEQUEIRA, J. L.; ADREATTI FILHO, R. L. Proventricular dilatation disease (PDD) and megaesophagus in a blue-fronted parrot amazon Amazona aestiva - case report. Vet e Zootec., v. 16, n. 1, p. 69-73, 2009.

McLELLAND, J. Sistema digestório das aves. In: GETTY, R. Sisson/Grossman: anatomia dos animais domésticos. 5. ed. Rio de Janeiro: Guanabara Koogan, 1986. p. $1445-1464$.

MCMILLAN, M. C. Imaging techniques. In: RITCHIE, B. W.; HARRISON, G. J.; HARRISON, L. R. Avian medicine: principles and application. Lake Worth: Wingers, 1994. p. 246-326.

MCMILLAN, M. C. Imaging techniques. In: RITCHIE, B. W.; HARRISON, G. J.; HARRISON, L. R. (Ed.). Avian medicine: principles and application. Delray Beach (FL): HBD International Inc, 1999. p. 246-261.

MORRISEY, J. K. Gastrointestinal diseases of psittacine birds. Semin. Avian Exotic Pet Med., v. 8, p. 66-74, 1999.

NICKEL, R.; SCHUMMER, A.; SEIFERLE, E. Anatomy of the domestic birds. Berlin: VerlagPaul Parey, 1977. p. 95-97.

O'MALLEY, B. Clinical anatomy and physiology of exotic species. Edinburgh: Elsevier Saunders, 2005. p. 95-161.

O'MEARA, D. C.; WITTER, J. F. Infectious and parasitic diseases of wild birds. Ames, lowa: lowa State University Press, 1971. p. 153-162.

PARISI, L.; CLUBB, S. What is your diagnosis? Jour of Avian Med and Surg., v. 24, n. 2, p. 152-154, 2010.

PEES, M. Radiography. In: CHITTY, J.; LIERZ, M. (Ed.). BSAVA manual of raptors, pigeons and passerine birds. Gloucester, UK: British Small Animal Veterinary Association, 2008. p. 114-120.

PETERSON, R. T. As aves. Rio de Janeiro: J. Olympio, 1971. p. 208. 
PETRAK, M. L.; GILMORE, C. E. Neoplasms. In: PETRAK, M. L. (Ed.). Diseases of cage and aviary birds. 2. ed. Philadelphia: Lea and Febiger, 1969. p. 606-637.

PINTO, A. C. B. C. Radiologia. In: CUBAS, Z. S.; SILVA, J. C. R.; CATÃO-DIAS, J. L. Tratado de animais selvagens. São Paulo: Roca, 2007. p. 896-919.

POUGH, F. H.; HEISER, J. B.; McFARLAND, W. N. A vida dos vertebrados. São Paulo: Atheneu Editora, 1999. p. 439-448.

REAVILL, D.; SCHMIDT, R. Lesions of the proventriculus/ ventriculus of pet birds: 1640 cases. In: ANNUAL MEETING OF THE ASSOCIATION OF AVIAN VETERINARIANS, 28., 2007, Rhode Island. Proceedings, 2007. p. 89-93.

RITCHIE, B. W.; GREGORY, C. R.; LATIMER, K. S.; PESTI, D.; ARD, M. Epizootiology of proventricular dilatation disease in breeding cockatiels. Proc Annu Conf Assoc Avian Vet., v. 204, p. 41-45, 2004.

ROSSKOPF, W. J .J. Common conditions and syndromes of canaries, finches, lories and lorikeets, lovebirds, and macaws. Semin Avian Exotic Pet Med., v. 12, p. 131143, 2003.

RUPLEY, A. E. Manual de clínica aviária. São Paulo: Roca, 1999. p. 213-242.

SANTOS, A. L. Q.; SOUZA, R. R.; MENEZES, T. L.; FERREIRA, C. H.; OLIVEIRA, S. H. P.; KAMINISHI, A. P. S.; ANDRADE, M. B.; NASCIMENTO, L. R. Anatomia comparada do tubo digestório de diferentes aves da ordem Psittaciformes. PUBVET, Londrina, v. 6, n. 13, 2012. Disponível em:

http://www.pubvet.com.br/artigos_det.asp?artigo=1232>. Acesso em: 25 fev. 2013.

SCHMIDT, R. E. Pathology of gastrointestinal disease in psittacine parrots. Sem Avian Exot Pet Med., v. 8, p. 75-82, 1999.

SCHMIDT, R. E.; REAVILL, D. R.; PHALEN, D. N. Pathology of pet and aviary birds. Ames: Blackwell Publishing, 2003. p. 67-93.

SCHWARZE, E. Compêndio de anatomia veterinária - anatomia de las aves. Zaragoza: Acribia, 1980. 212 p.

SHIVAPRASAD, H. L.; BARR, B. C.; WOODS, L. W.; DAFT, B. M.; MOORE, J. D.; KINDE, H. Spectrum of lesions pathology) of proventricular dilatation syndrome. Roc Annu Conf Assoc Avian Vet., v. 5, p. 505-506, 1995.

SICK, H. Ornitologia brasileira. Rio de Janeiro: Nova Fronteira, 2001. p. 17-19.

SILVERMAN, S. Técnica radiográfica para aves. In: TICER, J. W. Técnicas radiológicas na prática veterinária. 2. ed. São Paulo: Roca, 1987. p. 412-420.

SMITH, B. J.; SMITH, S. A. Radiology. In: ALTMAN, R. B.; CLUBB, S. L.; DORRESTEIN, G. M.; QUESENBERRY, K. (Ed.). Avian medicine and surgery. Philadelphia: WB Saunders, 1997. p. 170-199. 
SULLIVAN, N. D.; MACKIE, J. T.; MILLER, R. I.; GILES, A. First case of psittacine proventricular dilatation syndrome (macaw wasting disease) in Australia. Aust Vet J., v. 75, n. 9 , p. $674,1997$.

VINK-NOOTEBOOM, M.; LUMEIJ, J. T.; WOLVEKAMP, W. T. C. Radiography and image-intensified fluoroscopy of barium passage through the gastrointestinal tract in six healthy amazon parrots (Amazona Aestiva). Veterin Radiol \& Ultras., v. 44, p. 43-48, 2003.

WALLACH, J. D.; BOEVER, W. J. Diseases of exotic animals: medical and surgical management. Philadelphia: W. B. Saunders Company, 1983. p. 925-975.

WALSH, M. T.; Radiology. In: HARRISON, G. J.; HARRISON, L. R. Clinical avian medicine and surgery. Philadelphia: W. B. Saunders Company, 1986. p. 201-233.

WILLIAMS, J. Orthopedic radiography in exotic animal practice. The Veter Clin of North Amer: Exotic Animal Practice, v. 5, n. 1, p. 1-22, 2002.

WORELL, A. B. Crop disorders in Psittacines. Exotic Pet Practice, v. 5, n. 3, p. 1718, 2000.

WYSS, F.; DEB, A.; WATSON, R.; HAMMER, S. Radiographic measurements for PDD diagnosis in spix's araras (Cyanospitta spixi) at al wabra wildlife preservation (AWWP), Qatar. Proc Intern Conf Dis Zoo Wild Anim., v. 1, p. 349-354, 2009. 
ANEXOS

\section{ANEXO A - ANATOMIA SISTEMA DIGESTÓRIO DAS AVES}

Figura 5 - Sistema digestório das aves

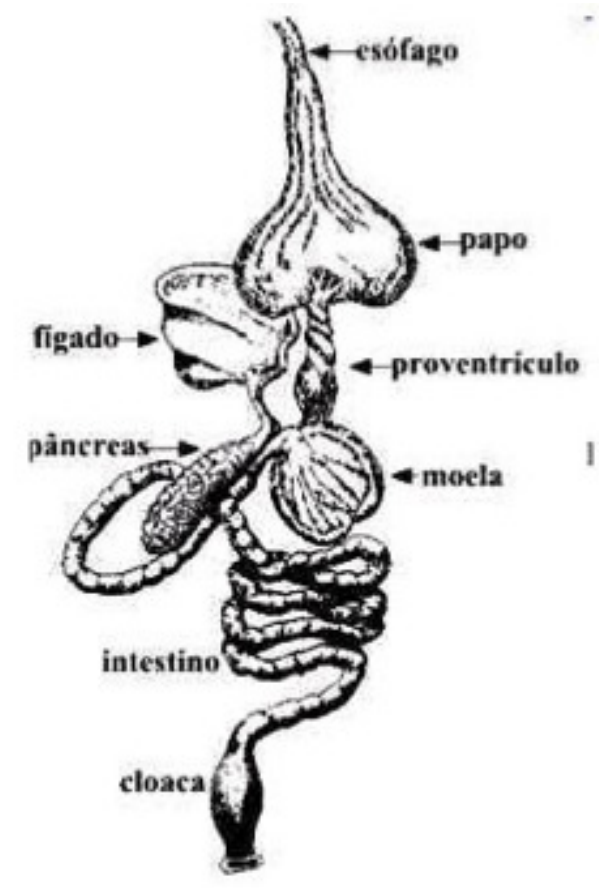

Fonte: www.colegiosaofrancisco.com.br/alfa/classe-aves/imagens /sistema-digestivo-da-ave-2.jpg 
ANEXO B - CAVIDADES GÁSTRICAS DAS AVES

Figura 6 - Cavidades gástricas dos psitacídeos

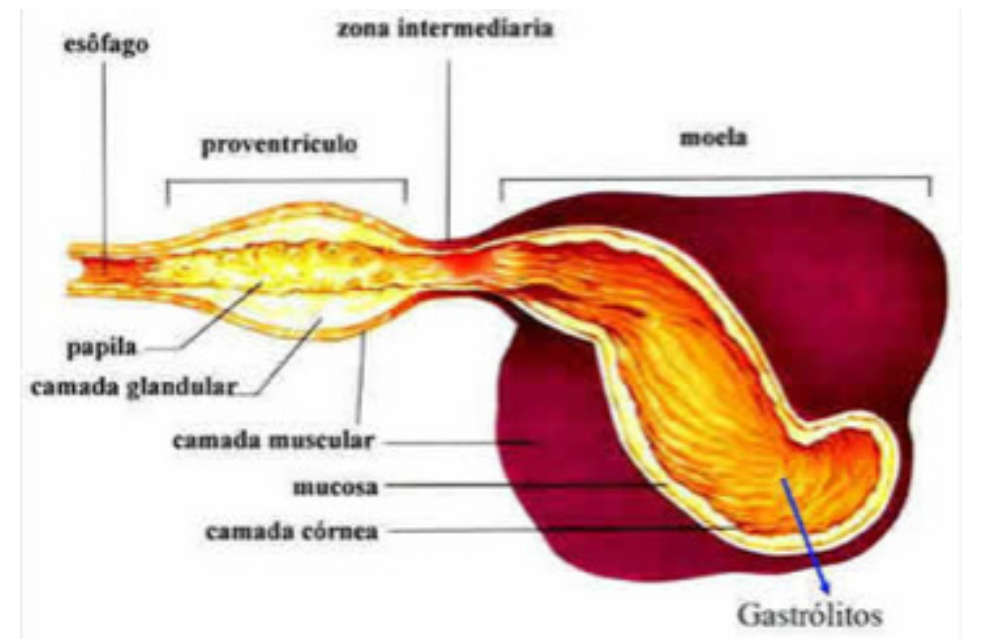

Fonte: http://www.portalsaofrancisco.com.br/alfa/classe-aves/sistema-digestivo-das-aves5.php 